\title{
Seawater reverse osmosis desalination and (harmful) algal blooms
}

\author{
Loreen O. Villacorte $^{\mathrm{a}, \mathrm{b}, *}$, S. Assiyeh Alizadeh Tabatabai ${ }^{\mathrm{a}, \mathrm{c}}$, Donald M. Anderson ${ }^{\mathrm{d}}$, Gary L. Amy ${ }^{\mathrm{a}, \mathrm{c}, \mathrm{e}}$, \\ Jan C. Schippers ${ }^{\mathrm{a}}$, Maria D. Kennedy ${ }^{\mathrm{a}, \mathrm{e}}$ \\ a UNESCO-IHE Institute for Water Education, Westvest 7, 2611 AX Delft, The Netherlands \\ ${ }^{\mathrm{b}}$ Wetsus Center of Excellence for Sustainable Water Technology, Agora 1, 8934 CJ Leeuwarden, The Netherlands \\ c Water Desalination and Reuse Center, 4700 KAUST, Thuwal, Saudi Arabia \\ d Biology Department, Woods Hole Oceanographic Institution, Woods Hole, MA 02543, USA \\ e Department of Civil Engineering and Geosciences, Delft University of Technology, Stevinweg 1, 2628 CN Delft, The Netherlands
}

\section{H I G H L I G H T S}

- A review of harmful algal blooms (HAB) from the perspective of desalination.

- Discussion on the impact of HABs on seawater reverse osmosis (SWRO) desalination.

- State-of-the-art of pretreatment technologies for SWRO during HABs.

- Review of indices to quantify effects of HABs on SWRO and pretreatment efficiency.

- Future outlook on pretreatment with regards to HABs and growth of SWRO application.

\section{G R A P H I C A L A B S T R A C T}

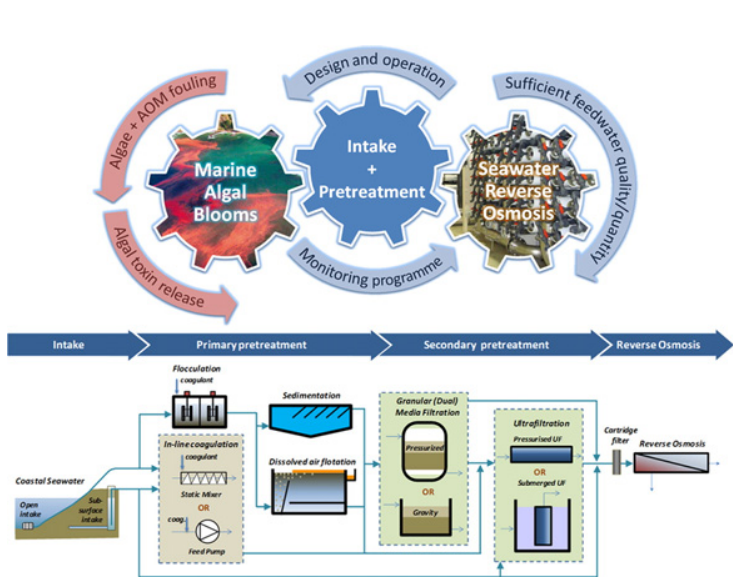

\begin{abstract}
A B S T R A C T
This article reviews the occurrence of HABs in seawater, their effects on the operation of seawater reverse osmosis (SWRO) plants, the indicators for quantifying/predicting these effects, and the pretreatment strategies for mitigating operational issues during algal blooms. The potential issues in SWRO plants during HABs are particulate/ organic fouling of pretreatment systems and biological fouling of RO membranes, mainly due to accumulation of algal organic matter (AOM). The presence of HAB toxins in desalinated water is also a potential concern but only at very low concentrations. Monitoring algal cell density, AOM concentrations and membrane fouling indices is a promising approach to assess the quality of SWRO feedwater and performance of the pretreatment system. When geological condition is favourable, subsurface intake can be a robust pretreatment for SWRO during HABs. Existing SWRO plants with open intake and are fitted with granular media filtration can improve performance in terms of capacity and product water quality, if preceded by dissolved air flotation or sedimentation. However, the application of advanced pretreatment using ultrafiltration membrane with in-line coagulation is often a better option as it is capable of maintaining stable operation and better RO feed water quality during algal bloom periods with significantly lower chemical consumption.
\end{abstract}

(c) 2015 Elsevier B.V. All rights reserved.

\footnotetext{
* Corresponding author at: UNESCO-IHE Institute for Water Education, Westvest 7, 2611 AX Delft, The Netherlands. E-mail addresses: l.villacorte@unesco-ihe.org, loreen.villacorte@gmail.com (L.O. Villacorte).
} 


\section{Contents}

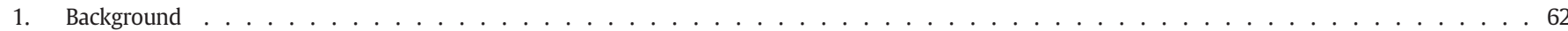

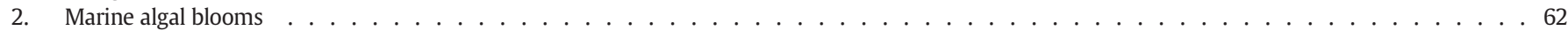

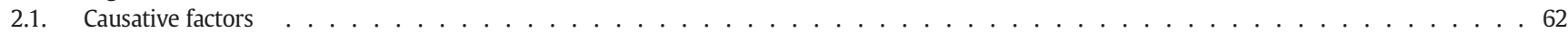

2.2. Harmful algal blooms $(\mathrm{HABs}) \ldots \ldots \ldots \ldots \ldots$

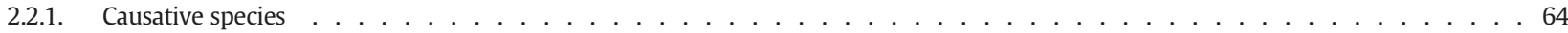

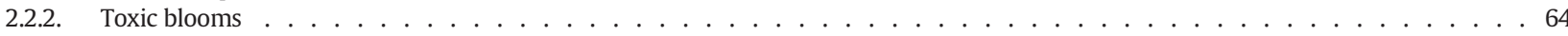

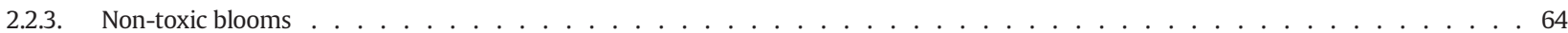

2.2.4. Macro-algal blooms . . . . . . . . . . . . . . . . . . . . . . . . . . . . . . . . . . . . . 65

2.2.5. Changing perspective on $\mathrm{HABs} \ldots \ldots \ldots \ldots$

2.3. Algal organic matter $(\mathrm{AOM}) \ldots \ldots \ldots \ldots \ldots$

2.3.1. Marine mucilage . . . . . . . . . . . . . . . . . . . . . . . . . . . . . 66

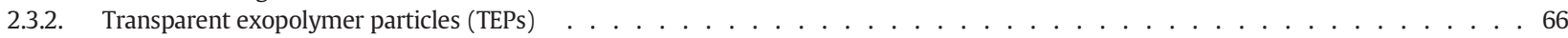

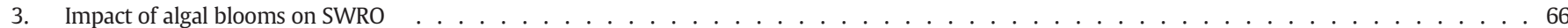

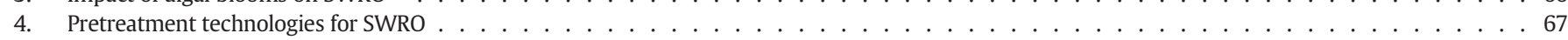

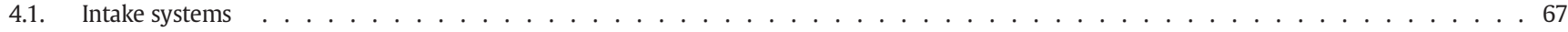

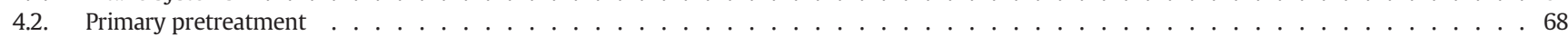

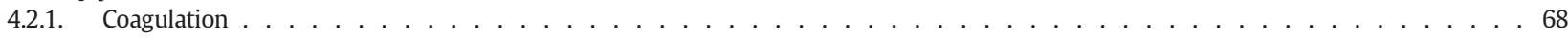

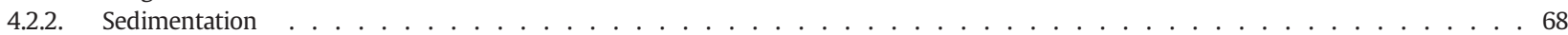

4.2.3. Dissolved air flotation $(\mathrm{DAF}) \ldots \ldots \ldots \ldots$

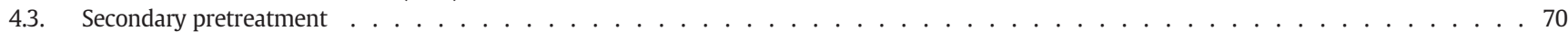

4.3.1. Granular media filtration $(\mathrm{GMF}) \ldots \ldots \ldots \ldots$

4.3.2. Ultrafiltration $(\mathrm{UF}) \ldots \ldots \ldots \ldots$

5. Algal bloom indicators for quantifying pretreatment efficiency . . . . . . . . . . . . . . . . . . . . 71

5.1. Algae concentration . . . . . . . . . . . . . . . . . . . . . . . . . . . . . . . 72

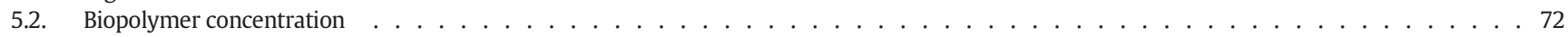

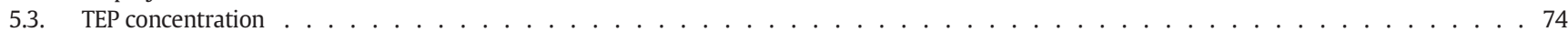

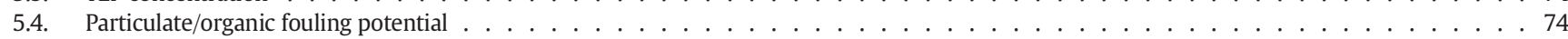

5.5. Biological fouling potential index . . . . . . . . . . . . . . . . . . . . . . . . . . 74

6. Strategies to control operational issues in SWRO plants during algal blooms . . . . . . . . . . . . . . . . . . . . . . . . . . . . . . . . . . 74

7. Future pretreatment challenges . . . . . . . . . . . . . . . . . . . . . . . . . . 75

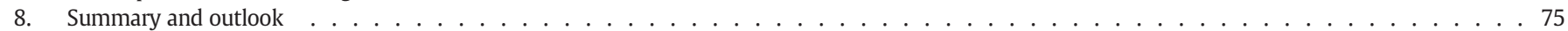

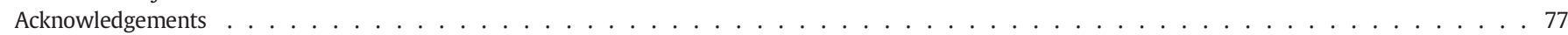

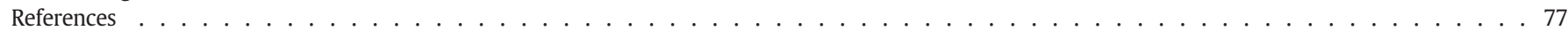

\section{Background}

Seawater reverse osmosis (SWRO) is currently the leading and preferred technology for seawater desalination [43]. The main drawback for cost-effective application of SWRO is membrane fouling [14,54, 113]. The accumulation of particulate and organic material from seawater and biological growth in membrane modules frequently cause operational problems in SWRO plants. To reduce the (in)organic load of colloidal and particulate matter reaching RO membranes and to minimize or delay associated operational problems, pretreatment systems are generally installed upstream of the RO membranes. Most SWRO plants, especially in the Middle East, install coagulation followed by granular media filtration (GMF) to pre-treat seawater. However, in recent years, low pressure membrane filtration is increasingly being used as SWRO pretreatment.

Over the years, it is becoming more evident that microscopic algae are a major cause of operational problems in SWRO plants [36,171]. The adverse effect of algae on SWRO started to gain more attention during a severe "red tide" bloom incident in the Gulf of Oman in 2008-2009 (Fig. 1). This "red tide" (hereafter termed as harmful algal bloom or $\mathrm{HAB}$ ) forced several SWRO plants in the region to reduce or shutdown operation [134] due to clogging of pretreatment systems (mostly GMF) and/or due to unacceptable RO feed water quality. The latter have triggered concerns of irreversible fouling problems in RO membranes which eventually led to shutdown of some plants [22,111,118, 134]. This incident highlighted a major problem that algal blooms may cause in countries relying largely on SWRO plants for their water supply, and underlines the importance of adequate pretreatment in such systems.
This article reviews the typical dynamics of (harmful) algal blooms in marine environment, their effects on the operation of seawater reverse osmosis (SWRO) plants, the indicators for quantifying/predicting these effects, and the pretreatment strategies for mitigating operational issues in SWRO plants during algal blooms.

\section{Marine algal blooms}

All life in the sea depends on the primary producers - the marine algae and other microorganisms that convert $\mathrm{CO}_{2}$ into the biomass that forms the base of the marine food web (Fig. 2). Phytoplankton (floating or swimming marine algae) are a diverse group of organisms comprised of thousands of species. Each has a set of environmental conditions that favour growth and proliferation, and thus there is a continuous succession of species through time in a given area. These are termed "blooms", and can range from dilute suspensions of cells to dense accumulations that can make the water appear discoloured. Algal blooms are critical to many aspects of marine ecology as well as to human society's utilisation of marine resources. There are, however, also negative impacts from algal blooms, as detailed in succeeding sections.

\subsection{Causative factors}

The growth and accumulation of individual algal species in a mixed assemblage of marine organisms are exceedingly complex processes involving an array of chemical, physical, and biological interactions [11]. Given the diverse array of algae from several different classes that cause problems in a variety of oceanographic systems, attempts to 


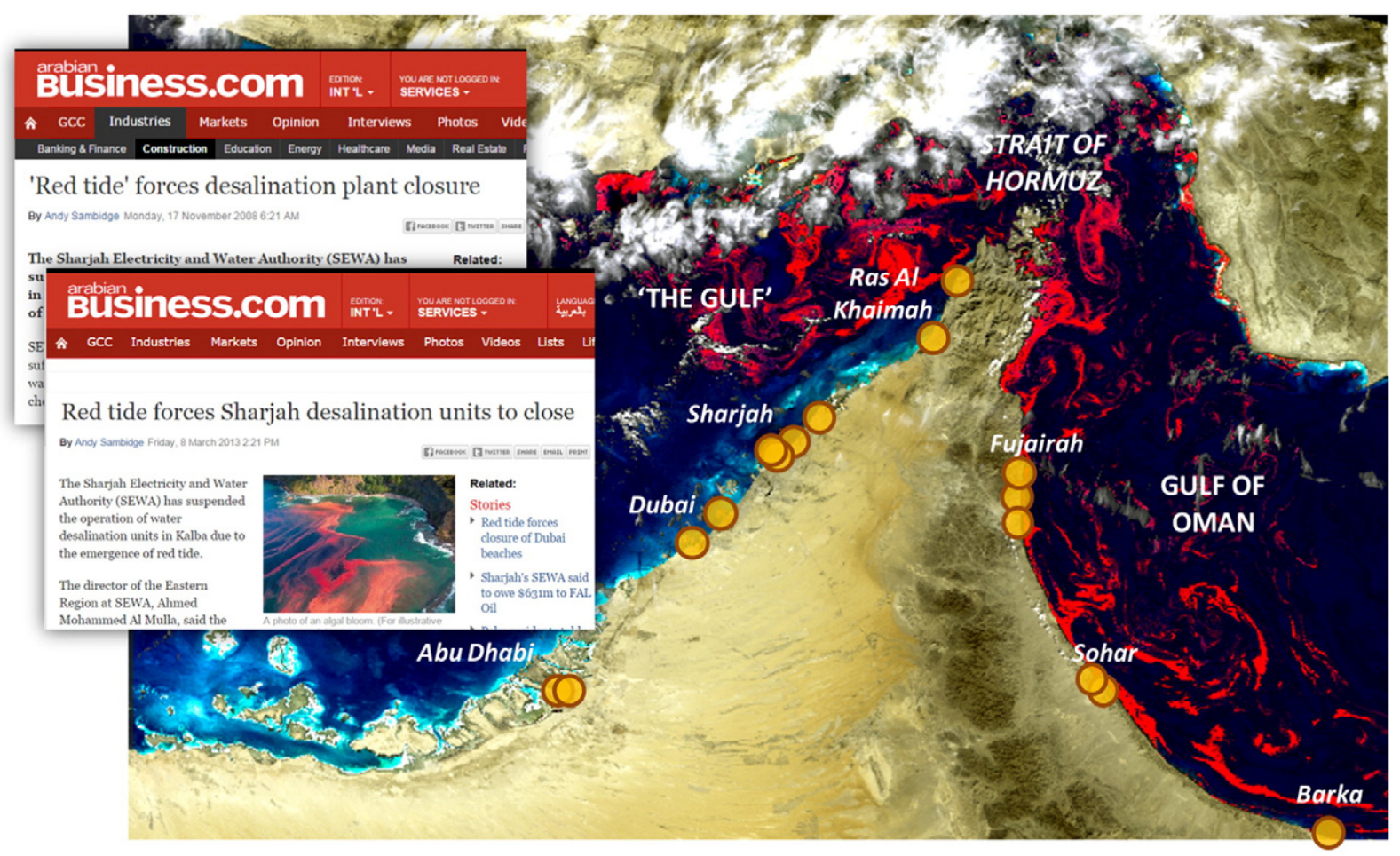

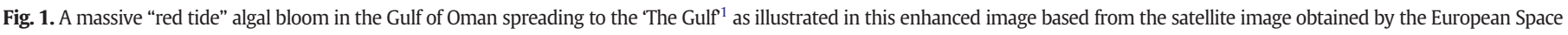

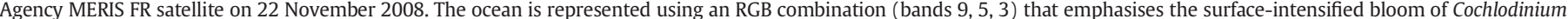

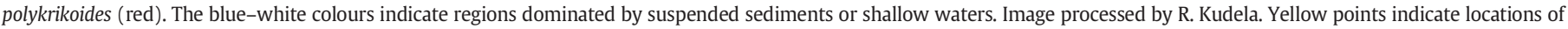
major SWRO plants in the area. Inset images are screenshots of online news regarding SWRO plant shutdown due to HABs in the region in 2008 and 2013 (www.arabianbusiness.com).

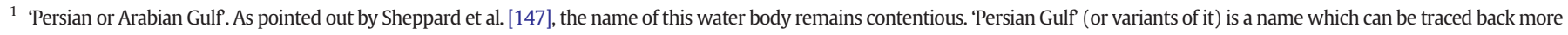

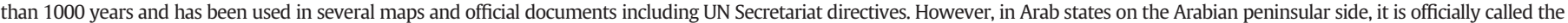
'Arabian Gulf. In this article, we use the term 'The Gulf' when referring to this water body hoping that the omission of geographic descriptors will be less offensive to some parties.

generalize the bloom dynamics of bloom-forming species are doomed to failure. Some common mechanisms can nevertheless be highlighted.

In addition to sunlight, the distribution and concentration of algae in the ocean can be greatly influenced by natural physico-chemical variations (e.g., temperature, current, salinity, nutrient load, etc.; [146]). Nutrients such as nitrogen $(\mathrm{N})$, phosphorus $(\mathrm{P})$ and silicon $(\mathrm{S})$ and many trace metals and vitamins are among the most important of these factors, with two major sources - natural and anthropogenic. Natural phenomena such as storm events can increase river discharges of nutrients to the sea while strong winds can induce mixing and transport of nutrients from the lower water column to the surface where they can be utilised by algae $[152,165]$. Coastal upwelling, which is driven by the combination of wind, the Coriolis effects, and Ekman drift, is a major factor for the transport of nutrients from the bottom of the sea

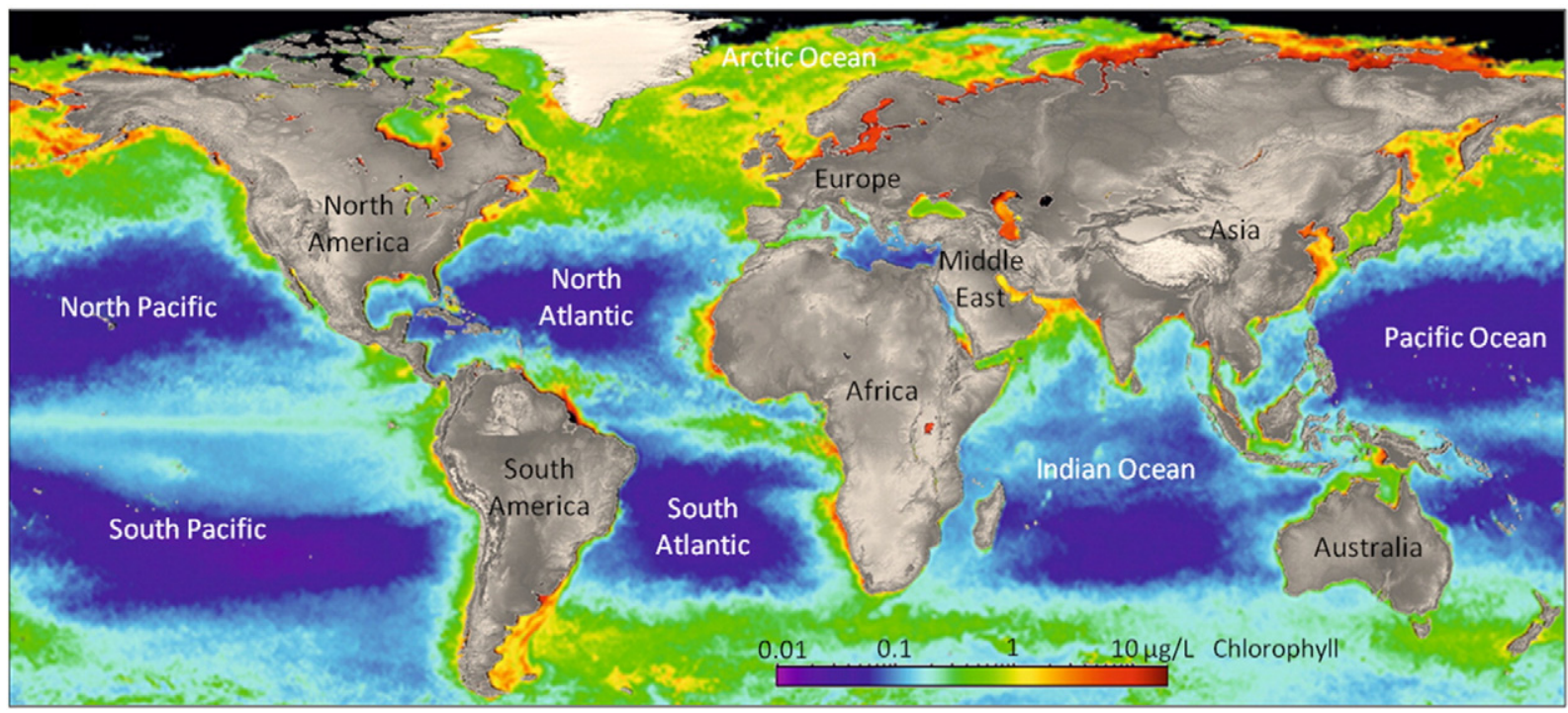

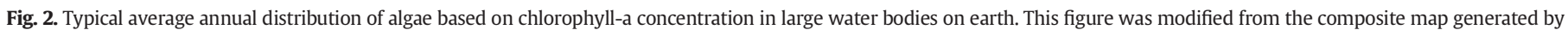
Gledhill and Buck [61] based on the Aqua MODIS chlorophyll composite for year 2009 (http://oceancolor.gsfc.nasa.gov/cgi/l3). 
to the surface $[15,107]$. Wind-driven dust events carrying iron-rich aerosols from the Sahara Desert have been reported to influence the frequency and severity of algal blooms on the Florida coast, on the other side of the Atlantic [184]. A similar scenario may have occurred after dust events around the Yellow Sea [148] and 'The Gulf' [69,112].

Human activities can also contribute to algal blooms by increasing nutrient loadings in coastal seawater through direct/indirect discharge of un/poorly-treated wastewater and run-off of untreated livestock wastes and residual fertilisers from agricultural areas. Increased incidence of HABs has been shown to have substantial correlation with growing human populations, and with higher fertiliser use and livestock production $[7,146]$. Many regions in the world that have implemented stricter environmental regulations to limit anthropogenic nutrient discharges to rivers have observed localised reduction in algal blooms, as in the case of the Seto Inland Sea in Japan [114].

\subsection{Harmful algal blooms (HABs)}

Virtually every coastal country in the world can be affected by HABs (commonly called "red tides"). This diverse array of phenomena includes blooms of toxic, microscopic algae that lead to illness and death in humans, fish, seabirds, marine mammals, and other oceanic life (reviewed in [11]). There are also non-toxic HABs that cause damage to ecosystems, fisheries resources, and to commercial and recreational facilities, often due to the sheer biomass of the accumulated algae. The term "HAB" also applies to non-toxic macroalgae (seaweeds), which can cause major ecological impacts such as the displacement of indigenous species, habitat alteration and oxygen depletion in bottom waters, or societal impacts such as the fouling of beaches and disruption of recreational and commercial activities, including intake of water for cooling or desalination. The frequency, spatial extent, and economic impact of HABs have all expanded in recent decades, in parallel with, and sometimes a result of, the world's increasing exploitation on the coastal zone for shelter, food, recreation, and commerce [8,11,67].

A common misconception is that HABs are caused by the explosive growth of a single species that rapidly dominates the water column. It is only necessary, however, to have conditions that favour the growth and dominance of a moderately large population of a given species, and the proper hydrographic and meteorological conditions to permit the accumulation of those organisms. In other words, winds, tides, currents, fronts, and other features can create discrete patches of cells of streaks of red water at all scales. In some cases, however, HAB species are able to form nearly mono-specific blooms, benefitting from mechanisms such as grazer avoidance (through swimming, migration patterns, or even cell morphology, for example), or the inhibition of other, competing phytoplankton species, such as through the release of allelopathic substances (see reviews in $[38,92]$ ).

HABs in temperate and high latitudes are predominantly spring, summer, and fall phenomena. Some commonly occur during periods when heating or fresh water runoff creates a stratified surface layer overlying colder, nutrient rich waters. This situation favours dinoflagellates and other motile algae, as they are able to regulate their position and access nutrients below the pycnocline. Some of the motile HAB species can swim at speeds in excess of $10 \mathrm{~m}$ per day, and some undergo marked vertical migration, in which they reside in surface waters during the day to harvest the sunlight and then swim to the pycnocline and below to take up nutrients at night. This strategy can explain how dense accumulations of cells can appear in surface waters that are devoid of nutrients and which would seem to be incapable of supporting such prolific growth. This vertical migration is a factor of concern to desalination facilities, where intakes might see episodic pulses of algal cells during the daily migrations near intakes.

Horizontal transport of blooms is also an important feature of many HABs, often over hundreds or even thousands of kilometres. Major toxic outbreaks can suddenly appear at a site due to the transport of established blooms from other areas by ocean currents. Advance warning of imminent outbreaks is thus possible with the appropriate tools (e.g., satellite optical sensors and numerical forecast models).

\subsubsection{Causative species}

All phytoplankton bloom, in the sense that they increase and decrease in abundance through time, are typically preceded and followed by blooms of other species. Some species, however, are noted for their ability to form dense blooms, typically because of the harm those accumulations of cells can cause. About $60-80$ species out of $~ 300$ bloomforming algal species have been reported to cause HABs [150]. Some of these are listed in Table 1 to provide an example of the range of species, cell sizes, cell concentrations, and impacts, but there are many more species that are not listed. There is a wide variety of marine bloom-forming algae, with sizes that range from 2 to $2000 \mu \mathrm{m}$. Depending on the species, severe or harmful marine algal blooms can occur with cell concentrations from few thousands cells per ml to several hundred thousand cells per ml.

\subsubsection{Toxic blooms}

$\mathrm{HAB}$ phenomena take a variety of forms, with multiple impacts. One major category of impact occurs when toxic phytoplankton are filtered from the water as food by shellfish which then accumulate the algal toxins to levels which can be lethal to humans or other consumers. The poisoning syndromes have been given the names paralytic, diarrhetic, neurotoxic, amnesic, and azaspiracid shellfish poisoning (Table 2). Therapeutic intervention is primarily limited to symptomatic treatment and life support.

The toxins produced by some HAB species are among the most potent natural poisons known [166]. Saxitoxin, for example, is 1000 times more potent than cyanide, and 50 times stronger than curare. Many of the toxin classes are not single chemical entities, but instead represent families of compounds of similar chemical structure. A single species typically produces multiple derivatives or congeners within a toxin family. Humans are exposed to algal toxins principally by consumption of contaminated seafood products, although several types of toxin (brevetoxin and palytoxin) also cause respiratory asthma-like symptoms because of aerosol formation due to wave action. An emerging concern is the potential for HAB toxins to be retained in treated water during desalination operations, though several studies indicate that $>99 \%$ removal can be achieved through pretreatment (e.g., [45]) or through direct thermal or reverse osmosis operations [89]. Acute single-dose lethality of seafood toxins has been extensively studied, but chronic and/or repeated exposure to low toxin concentrations, which might be the case with low levels of toxin in desalinated water, has not been adequately examined.

\subsubsection{Non-toxic blooms}

Non-toxic blooms of algae can cause harm in a variety of ways. One prominent mechanism relates to the high biomass that some blooms achieve. When this biomass begins to decay as the bloom terminates, oxygen is consumed, leading to widespread mortalities of all plants and animals in the affected area. These types of blooms are sometimes linked to excessive pollution inputs, but can also occur in relatively pristine waters.

Another impact from high-biomass blooms is the disruption of desalination operations, as discussed in detail in this work. One example is the massive Cochlodinium polykrikoides bloom in the Gulf of Oman in 2008/2009 that affected a large number of RO desalination plants, closing some for as long as two months not because of toxins but mainly due to operational problems caused by the high load of algal cells and algalderived mucilage in the intake seawater [134]. Other dinoflagellate species, such as Gonyaulax hyaline/fragilis (e.g., [100]), are also known to secrete large amounts of mucilage in culture and have been identified as the major cause of massive production of mucilage at some events in New Zealand and the Mediterranean Sea. The diatom Cylindrotheca closterium has been linked to major mucilage events in the Northern 
Table 1

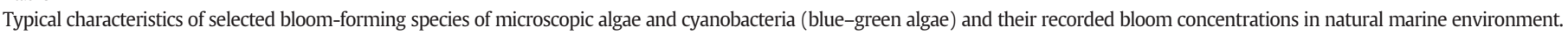

\begin{tabular}{|c|c|c|c|c|c|c|c|}
\hline \multirow[t]{2}{*}{ Group } & \multirow[t]{2}{*}{ Bloom-forming species } & \multirow[t]{2}{*}{ Cell shape ${ }^{a}$} & \multirow[t]{2}{*}{ Cell size $\mu \mathrm{m}^{\mathrm{a}}$} & \multicolumn{2}{|c|}{ Algal concentration ${ }^{\mathrm{b}}$} & \multirow[t]{2}{*}{ Potential impact to marine environment } & \multirow[t]{2}{*}{ References } \\
\hline & & & & cells/mL & $\mu g$ chl-a/L & & \\
\hline \multirow[t]{5}{*}{ Dinoflagellates } & Alexandrium spp. & $\mathrm{RE}$ & $25-32$ & 7000 & - & Toxins & Selina et al. [145] \\
\hline & Cochlodinium polykrikoides & $\mathrm{RE}$ & $20-40$ & 48,000 & - & Toxins, hypoxia & Kim [83] \\
\hline & Karenia brevis & $\mathrm{RE}$ & $20-40$ & 37,000 & - & Toxins, hypoxia & Tester et al. [162] \\
\hline & Noctiluca scintillans & $\mathrm{Sp}$ & $200-2000$ & 1900 & - & Hypoxia & Fonda-Umani et al. [56] \\
\hline & Prorocentrum spp. & $\mathrm{FE}$ & $30-60$ & 70,000 & $\sim 200$ & Hypoxia & Taş and Okuş [158] \\
\hline \multirow[t]{4}{*}{ Diatoms } & Chaetoceros spp. & OC & $8-25$ & 30,100 & 14 & Hypoxia & Booth et al. [31] \\
\hline & Pseudo-nitzschia spp. & $0.8^{*} \mathrm{PP}$ & $3-100$ & 19,000 & - & Toxins, hypoxia & Anderson et al. [6] \\
\hline & Skeletonema costatum & $\mathrm{Cy}$ & $2-25$ & 88,000 & - & Hypoxia & Shikata et al. [149] \\
\hline & Thalassiosira spp. & $\mathrm{Cy}$ & $10-50$ & 28,000 & $\sim 100$ & Hypoxia & Maier et al. [101] \\
\hline \multirow[t]{2}{*}{ Haptophytes } & Emiliania huxleyi & $\mathrm{Sp}$ & $2-6$ & 115,000 & - & Hypoxia & Berge [21] \\
\hline & Phaeocystis spp. & $0.9 * \mathrm{Sp}$ & $4-9$ & 52,000 & - & Hypoxia & Janse et al. [81] \\
\hline \multirow[t]{2}{*}{ Raphidophytes } & Chattonella spp. & $\mathrm{Co}+0.5 * \mathrm{Sp}$ & $10-40$ & 10,000 & - & Toxins, hypoxia & Orlova et al. [116] \\
\hline & Heterosigma akashiwo & Sp & $15-25$ & 32,000 & - & Toxins, hypoxia & Shikata et al. [149] \\
\hline Cyanobacteria & Nodularia spp. & Cy & $6-100$ & 605,200 & - & Toxins, hypoxia & McGregor et al. [102] \\
\hline
\end{tabular}

Legend: $\mathrm{RE}=$ rotational ellipsoid; $\mathrm{Sp}=$ sphere; $\mathrm{FE}=$ flattened ellipsoid; $\mathrm{OC}=$ oval cylinder; $\mathrm{PP}=$ parallelepiped; $\mathrm{Cy}=$ cylinder; $\mathrm{Co}=$ cone; $\mathrm{O}_{2}=$ dissolved oxygen.

a Equivalent geometric dimensions and size range of algal cells based on Olenina et al. [115].

b Maximum recorded concentrations reported in reference literature.

Adriatic Sea, stimulated by nutrient loadings from the Po and other rivers [133]. Large standing stocks of phytoplankton build up and extracellular polymers, mainly polysaccharides, accumulate in the stratified water column. Some of the mucilage outbreaks formed by phytoplankton populations have been linked to high N/P ratios and increased stratification in coastal waters, and thus are at least partially reflective of human perturbations to the nutrient balance of coastal waters [40].

\subsubsection{Macro-algal blooms}

Over the past several decades, blooms of macroalgae (seaweeds) have been increasing along many of the world's developed coastlines. Macroalgal blooms occur in nutrient-enriched estuaries and nearshore areas that are shallow enough for light to penetrate to the sea floor. These blooms have a broad range of ecological and societal effects, and often last longer than "typical" phytoplankton HABs. Some, like the spectacular "green tides" of northeast China [151] are floating masses of seaweed that can pose significant problems to power plants, desalination plants, and recreational resources in many areas.

\subsubsection{Changing perspective on $H A B s$}

Many are now re-evaluating the way that algal blooms are viewed, and in particular, which species are considered harmful. The term HAB has always been broad, as it was intended to include toxic blooms as well as those that cause harm in other, diverse ways, as described above. Despite the long list of HAB impacts that are well known and recurrent throughout the world, new impacts will emerge going forward, and with that will come the designation of new harmful species [9]. One current example is with desalination plants. The global and regional expansion of HABs is occurring at a time when there is also an increase in the construction of desalination plants to produce drinking water. Recurrent impacts are thus highly likely.

Table 2 presents data on the molecular size of the major HAB toxins, and all can be seen to be large enough to be removed routinely by RO membranes. However, it is now clear that algal species can produce organics that pass through pretreatment processes, forming gels or polymers (e.g., transparent exopolymeric particles or TEPs; [23]) or extracellular polymeric substances (EPS; [52]) that are either the direct or indirect cause of organic and/or biofouling in RO membranes. These are discussed in detail in Section 3.0. These compounds can be seriously disruptive, particularly to those plants that use RO to produce fresh water. Since economic considerations are leading to a proportional expansion in RO desalination plants compared to those that use thermal processes, it can be expected that many more impacts of HABs on desalination facilities will arise than have been recorded thus far. It is thus very likely that species that are not generally considered harmful to other sectors of society will be harmful to these plants because they produce disproportionally large amounts of dissolved organic materials. Eventually, a list of species that are prolific producers of harmful organic compounds (that are not toxins) will be generated and used by desalination plant operators to plan mitigation strategies. Table 2 is an example of such a listing with a focus on toxin-producing species, and Table 1 for HABs in general.

Yet another interesting change in the perception of what is harmful comes from countries that are heavily dependent on their coastal waters for aquaculture and capture fisheries, particularly those with very dense operations such as in China, Japan, Korea, and other Asian countries. Here we are seeing a distinction being made between HABs and FABs or "favourable algal blooms" as countries are recognizing that phytoplankton biomass needs to be at a relatively high level to support such

Table 2

Typical characteristics of common marine HAB toxins.

\begin{tabular}{|c|c|c|c|c|}
\hline Poisoning syndrome & Toxins & $\begin{array}{l}\text { Molecular } \\
\text { formula }^{\mathrm{a}}\end{array}$ & $\begin{array}{l}\text { Molecular } \\
\text { weight (Da) }\end{array}$ & Causative species \\
\hline Paralytic shellfish poisoning (PSP) & Saxitoxins & $\mathrm{C}_{10} \mathrm{H}_{17} \mathrm{~N}_{7} \mathrm{O}_{4}$ & 299.29 & $\begin{array}{l}\text { Alexandrium spp., Pyrodinium bahamense, Gymnodinium catenatum, } \\
\text { Anabaena spp., Aphanizomenon spp., Cylindrospermopsis spp., } \\
\text { Lyngbya spp., Planktothrix spp. }\end{array}$ \\
\hline Neurotoxic shellfish poisoning (NSP) & Brevetoxins & $\mathrm{C}_{50} \mathrm{H}_{70} \mathrm{O}_{14}$ & 895.08 & $\begin{array}{l}\text { Karenia brevis, Chattonella verruculosa, and possibly: } \\
\text { K. brevisculcatum, K. selliformis, K. papilionacea, K. mikimotoi }\end{array}$ \\
\hline Diarrhetic shellfish poisoning (DSP) & $\begin{array}{l}\text { Dinophysis toxins } \\
\text { - Okadaic acid } \\
\text { - Pectenotoxins }\end{array}$ & $\begin{array}{l}\mathrm{C}_{44} \mathrm{H}_{68} \mathrm{O}_{13} \\
\mathrm{C}_{47} \mathrm{H}_{70} \mathrm{O}_{14}\end{array}$ & $\begin{array}{l}805.00 \\
859.05\end{array}$ & Dinophysis spp., Prorocentrum lima \\
\hline Amnesic shellfish poisoning (ASP) & Domoic acid & $\mathrm{C}_{15} \mathrm{H}_{21} \mathrm{NO}_{6}$ & 311.33 & Pseudo-nitzschia spp., Nitzschia navis-varingica, Chondria armata \\
\hline Azaspiracid shellfish poisoning (AZP) & Azaspiracids & $\mathrm{C}_{47} \mathrm{H}_{71} \mathrm{NO}_{12}$ & 842.07 & Azadinium spinosum \\
\hline
\end{tabular}

a Formula given for parent toxin compound only. 
operations [9]. In this sense, algal blooms, even dense, high biomass ones, can be considered beneficial, and thus efforts to reduce pollution or other nutrient inputs as a general bloom mitigation strategy may not be supported by certain sectors of society, such as fishermen. One wonders if this view of favourable, high-biomass algal blooms will become more prevalent as countries and agencies worldwide are under increased pressure to maximize coastal fisheries productivity to feed their growing populations [9], placing two sectors of society (the fishing and desalination industries) at cross purposes.

\subsection{Algal organic matter (AOM)}

The natural organic matter (NOM) present in the aquatic environment is a mixture of diverse organic compounds originating from both autochthonous (local input) and allochthonous (external input) sources [91]. Algae are a major source of autochthonous NOM in the Earth's oceans, accounting for about half the organic matter input [51]. These algae-derived substances are collectively known as algal (or algogenic) organic matter (AOM).

Algal blooms, especially diatom blooms, are often responsible for the highest annual pulses of AOM production in the ocean [33]. Algal blooms (harmful or non-harmful) produce various forms and differing concentrations of AOM comprising mainly polysaccharides, proteins, lipids, nucleic acids and other dissolved organic substances $[26,41,55$, 109]. Myklestad [109] highlighted the significance of extracellular polysaccharides as they may comprise $>80 \%$ of AOM production. A significant fraction of these exopolysaccharides are highly surface-active and sticky and has been suspected to play a major role in the aggregation dynamics of algae during bloom events [106,109].

There are two types of AOM, namely: (1) organic substances released during the metabolic activity of algae known as extracellular organic matter (EOM) and (2) substances released through autolysis and/ or during the process of cell decay, termed intracellular organic matter (IOM). Algal cells excrete EOM mostly in response to nutrient stress and other unfavourable conditions (e.g., light, $\mathrm{pH}$ and temperature) or invasion by bacteria or viruses $[55,95,108]$. EOM substances can be either discrete or remained attached (bound) to the algal cell as coatings. Discrete EOMs often contain mainly polysaccharides and tend to be more hydrophilic while bound EOM contain more proteins and tend to be more hydrophobic [130]. On the other hand, IOMs comprise mainly low molecular weight polymers released from the interior of compromised, dying or deteriorating cells, which sometimes carry toxins, and taste and odour compounds [46,97]. Considering the conditions of how they are released, the contribution of IOM to the total AOM production is expected to increase during the stationary-death phase of an algal bloom.

\subsubsection{Marine mucilage}

Marine mucilage is a phenomenon characterized by the appearance of a sporadic but massive accumulation of gelatinous material at and below the water surface [93]. It is generally a result of excessive production of EOM during an algal bloom in response to low nutrient $(\mathrm{P}, \mathrm{N}, \mathrm{Si})$ stress and/or invasion by pathogens [103]. Severe mucilage events occasionally occur in the North Sea, Adriatic Sea and other parts of the Mediterranean region but proliferation of smaller mucilage aggregates such as "marine snow" has been commonly reported in oceanic and marine systems $[63,88,103,135]$. In the North Sea, the colony-forming Phaeocystis has been identified as the main culprit of the mucilaginous phenomena [88]. In the Adriatic Sea, it is mainly attributed to EOM production by diatoms (e.g., Nitzschia closterium, Chaetoceros affinis, Cylindrotheca closterium, and Skeletonema costatum) but some cyanobacteria and benthic macroalgae may have been likely involved as well $[77,103]$.

Marine mucilage has been reported in different forms: marine snow ( $>0.5 \mathrm{~mm}$ diameter), strings ( $2-15 \mathrm{~cm}$ long), tapes and clouds of up to several kilometres long. The mucilaginous aggregates are a heterogeneous consolidation of inorganic particles, biogenic debris/exudates (including transparent exopolymer particles; see Section 2.3.2) and dead and living organisms, including healthy eukaryotes and prokaryotes [3,93]. The aggregates are generally unstable and tend to change in size, shape and colour (becoming progressively darker with age) over time. Weather and wave conditions in the sea can dictate the formation and termination of the phenomenon, as a storm event can disperse the mucilage aggregates over a short period of time [103].

\subsubsection{Transparent exopolymer particles (TEPS)}

High molecular weight, hydrophilic, anionic muco-polysaccharides and glycoproteins, are essential components of marine mucilage. Such substances are collectively known as transparent exopolymer particles (TEPs; see review by [122]). During an algal bloom, TEPs mainly originate from algal-derived IOM and/or EOM components. Generally, TEPs are highly heterogeneous, both physically and chemically. Their volume and stability largely depends on environmental conditions while their chemical composition is known to be highly variable depending on the species releasing them and the prevailing growth conditions [122].

The observed size range of TEPs is typically 5 to $200 \mu \mathrm{m}$ as they oftentimes comprise an integral part of marine snow-sized aggregates $>500 \mu \mathrm{m}[4,123]$. Although TEPs were operationally defined as particles $(>0.40 \mu \mathrm{m})$, they are believed to form from much smaller colloidal polymers (TEP pre-cursors), perhaps fibrils as small as 1-3 $\mathrm{nm}$ in diameter and up to $100 \mathrm{~s}$ of $\mathrm{nm}$ in length [94,121].

In many aspects of particle dynamics in aquatic systems, TEPs have been associated with the natural coagulation and sedimentation of suspended particles $[122,125]$. They are known to be highly flexible and sticky, which might explain their tendency to aggregate into large flocs and to adhere to other materials [106]. Their relative stickiness was reported to be 2-4 orders of magnitude higher than most suspended particles in natural waters [122]. Because of their adhesive characteristic, TEPs can accumulate on solid-liquid interfaces and facilitate adsorption of suspended particles, including bacteria. The adsorbed and suspended TEPs can be colonised, degraded and may later serve as a substrate for bacteria $[4,123]$. Recently, Berman and co-workers proposed a "revised paradigm" of aquatic biofilm formation facilitated by TEPs emphasising the important role of TEPs in the conditioning and bacterial colonisation of surfaces (including reverse osmosis membranes) exposed to seawater $[16,20,24,25]$. The "revised paradigm" is illustrated and explained in detail in Fig. 3.

\section{Impact of algal blooms on SWRO}

Caron et al. [36] identified two potential impacts of (harmful) algal blooms on SWRO desalination facilities,

1) Significant treatment challenge to ensure the SWRO system is effectively removing algal toxins from seawater;

2) Operational difficulties due to increased total suspended solids and organic loading resulting from algal biomass in the raw water.

The presence of algal toxins during marine algal blooms is a major concern, since some of these toxins are highly potent neurotoxins [10, 11]. Studies on HAB toxin removal by RO are scarce and limited to laboratory bench-scale studies. These suggest that $99 \%$ removal can be achieved with RO membranes [28,89] or nanofiltration (e.g., [45]). Given the typical molecular weight size range of marine algal toxins of 0.3-0.9 Da (Table 2), RO is expected to be effective in rejecting these compounds. The adequacy of these rejection levels cannot be justified, as data from operational plants during toxic HABs is not available. The fact that some taste and odour compounds can pass through pretreatment and RO membranes may suggest that some of the smaller HAB toxins might do likewise, albeit in low concentrations. Although there are some WHO guidelines on freshwater algal toxins (e.g., microcystins), no WHO regulations are established for marine $\mathrm{HAB}$ toxins in drinking water. 
High algal biomass in raw water can cause operational problems in RO membranes. During filtration of algal bloom-impacted waters, particulate matter comprising algal cells, their detritus and AOM - if not effectively removed by the pretreatment process - can accumulate to form a heterogeneous and compressible cake layer on the surface of SWRO membranes. This may result in lower normalised flux and higher feed channel pressure drop, eventually leading to substantial loss of permeability. Considering the lower flux and higher operating pressure in SWRO, the direct relative impact of AOM accumulation on its operational performance is expected to be less severe compared to MF/UF systems. However, the accumulated sticky substances may initiate or promote particulate and biological fouling by enhancing deposition of bacteria and other particles from the feed water to the RO membrane and spacers $[24,188]$.

It is common knowledge that bacteria can adhere, accumulate and multiply in RO systems resulting in the formation of a slimy layer of dense concentrations of bacteria and their extracellular polymeric substances known as biofilm. When the accumulation of biofilm reaches a certain threshold that operational problems are encountered in the membrane system, it is considered as biological fouling or "biofouling" $[53,113]$. An operational problem threshold can be a significant (e.g., > 15\%) decrease of normalised membrane flux or increase in net driving pressure and/or an increase in feed channel pressure drop. In the Middle East, about 70\% of the seawater RO installations were reported to be suffering from biofouling problems [59]. Generally, biofouling is only a major problem in NF/RO systems because periodic backwashing and chemical cleaning in dead-end MF/UF systems allows regular dispersion or removal of most of the accumulated bacteria from the membrane; thereby inhibiting the formation of a biofilm.

Biofilm accumulation can be accelerated during algal blooms due to higher AOM concentration in seawater [172]. Some AOM components, specifically TEP, are characteristically sticky which make them likely to adhere and accumulate on the surface of the membranes and spacers. The accumulated TEP can serve as a "conditioning layer" - a good platform for effective attachment and initial colonisation of bacteria where bacteria can effectively utilise biodegradable nutrients from the feed water $[24,188]$. Furthermore, TEP can be partially degraded and

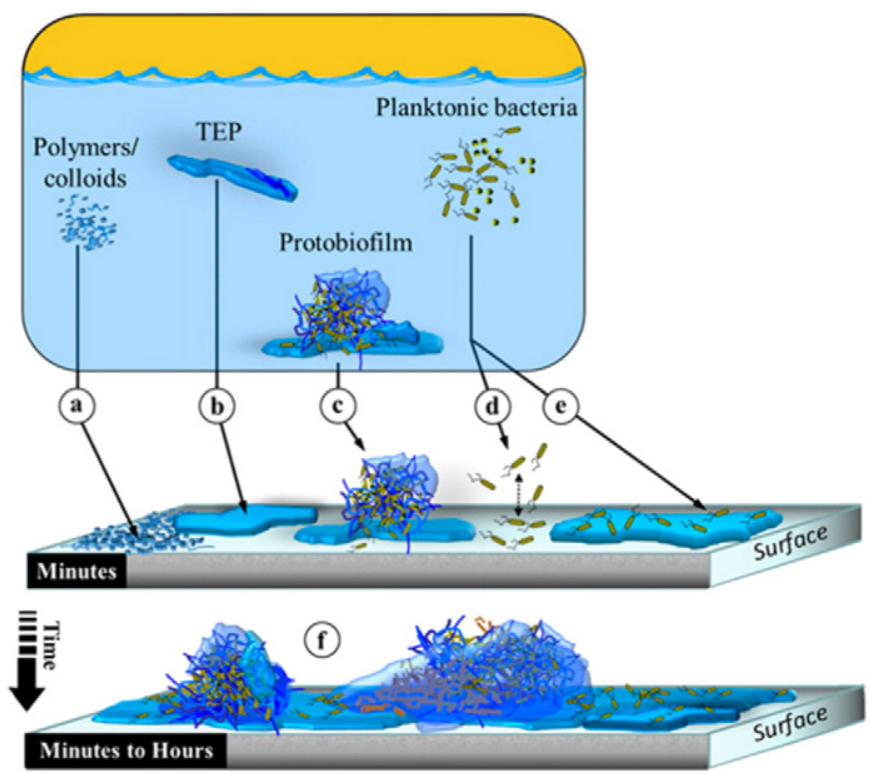

Fig. 3. Schematic illustration of the possible involvement of (a) colloidal biopolymers, (b) TEP, and (c) protobiofilm (suspended TEP with extensive microbial outgrowth and colonisation) in the initiation of aquatic biofilms. A number of planktonic bacteria (first colonisers) can attach (d) reversibly on clean surfaces or (e) irreversibly on TEP-conditioned surfaces. When nutrients are not limited in the water, (f) a contiguous coverage of mature biofilm can develop within a short period of time (minutes to hours). Figure and descriptions were adapted from Bar-Zeev et al. [16]. may later serve as a substrate for bacterial growth [4,123]. As illustrated in Fig. 3, TEP (and their pre-cursors) and protobiofilms (suspended TEP with extensive microbial outgrowth and colonisation) in surface water can initiate, enhance and possibly accelerate biofilm accumulation in RO membranes.

Since bacteria require nutrients for energy generation and cellular biosynthesis, essential nutrients such as biodegradable or assimilable organic carbon (BDOC or $\mathrm{AOC}$ ), phosphates and nitrates can be the main factors dictating the formation and growth of biofilm. During the peak of an algal bloom, some of these essential nutrients may be limited (e.g., phosphate) due to uptake by algae. However, when the bloom reaches a death phase, algal cells start to disintegrate and release some of these nutrients. Hence, biofouling initiated/enhanced by AOM may likely occur within a period of time after the termination of an algal bloom.

\section{Pretreatment technologies for SWRO}

To control fouling, most SWRO plants are equipped with one or more pretreatment systems. Pretreatment normally involves a form of filtration and other physical-chemical processes to remove suspended solids (particles, silt, algae, organics, etc.), oil and grease from the source water [186]. Pretreatment is generally categorized as primary pretreatment, consisting of coagulation in combination with a clarification process such as sedimentation or dissolved air flotation (DAF); and secondary pretreatment, consisting of a filtration process. Secondary pretreatment is classified as conventional when granular media filters (GMF) are applied and advanced when micro- and ultrafiltration (MF/ UF) membranes are used. The different pretreatment options and process schemes applicable to SWRO are illustrated in Fig. 4.

\subsection{Intake systems}

The intake system will have a significant influence on the quality of seawater coming into the SWRO desalination plant and therefore dictates the design of the pretreatment system. Currently, majority of SWRO plants operate with an open intake system, which means the pretreatment processes should be designed to handle variations in raw seawater quality while meeting the desired SWRO feed water quality. Over the recent years, various plants have been installed with subsurface intakes to improve the quality of seawater entering the SWRO plant and ultimately reduce process complexity of pretreatment systems in terms of design and operation.

Subsurface intake systems may include wells (vertical, angle, and radial) and galleries, which are either installed on the beach area or in the seabed (see [105]). This type of intake makes use of the natural geological properties of the coastal area to allow seawater to travel slowly through layers of sediments, sands and rocks, providing filtration and possibly active biological treatment before they enter the SWRO plant [104]. Such processes can substantially remove suspended solids, algae, bacteria, and dissolved organic carbon in seawater during algal blooms and therefore reduce the foulant load on the succeeding pretreatment processes $[42,105]$.

Installing subsurface intakes are favourable in coastal and near shore areas where the geological formation comprises permeable rocks, carbonates (limestones and/or dolomites), sand or gravel but they are often unfeasible in areas with low permeability rocky or muddy shoreline [105]. An example of successful large scale application of subsurface intake is the Fukuoka seawater desalination plant in Japan where seabed galleries $\left(103,000 \mathrm{~m}^{3} /\right.$ day capacity) of intake pipes were installed to extract seawater (with retention time of $\sim 7 \mathrm{~h}$ ) followed by UF pretreatment in front of the RO system as illustrated in Scheme J in Fig. 4. The capital costs for installing subsurface intakes can be slightly to significantly higher than in open-ocean intake systems, but significant savings in the operational cost of SWRO plant can be expected in the long term [105]. 


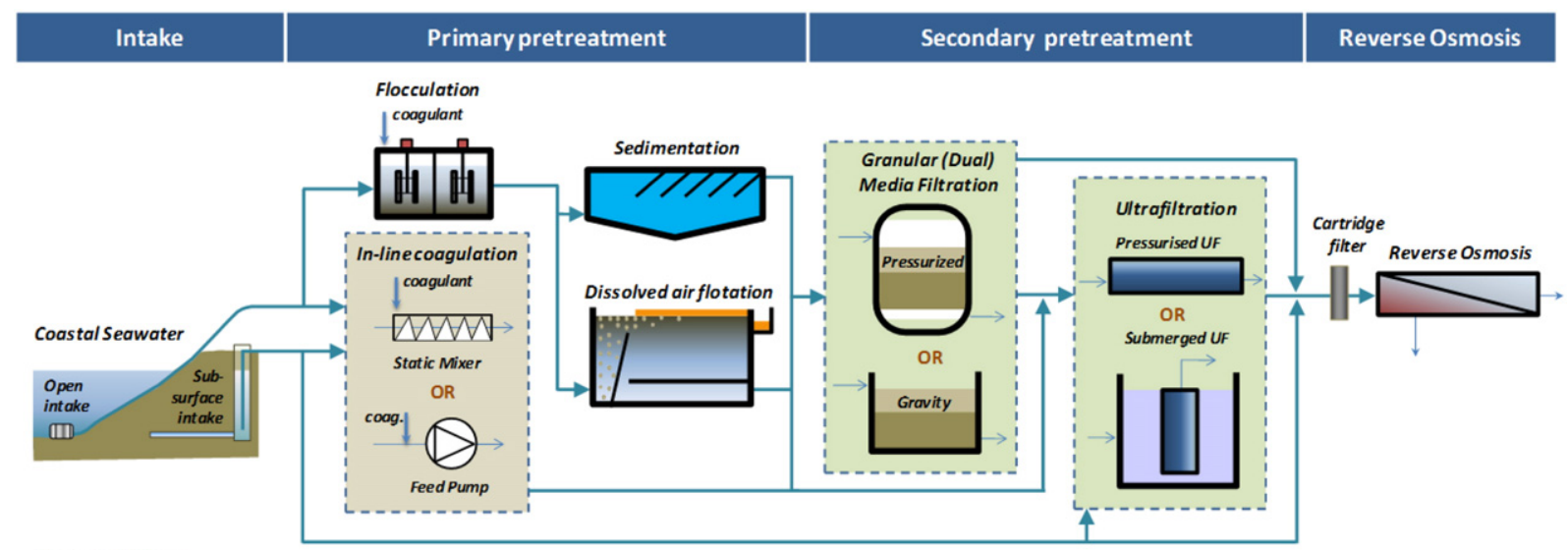

\section{Process Options}

Scheme A: Open intake $\rightarrow$ coag-flocculation $\rightarrow$ sedimentation $\rightarrow$ granular media filtration $\rightarrow$ ultrafiltration $\rightarrow$ cartridge filtration $\rightarrow$ RO

Scheme B: Open intake $\rightarrow$ coag-flocculation $\rightarrow$ sedimentation $\rightarrow$ granular media filtration $\rightarrow$ cartridge filtration $\rightarrow$ RO

Scheme C: Open intake $\rightarrow$ coag-flocculation $\rightarrow$ sedimentation $\rightarrow$ ultrafiltration $\rightarrow$ cartridge filtration $\rightarrow$ RO

Scheme D: Open intake $\rightarrow$ coag-flocculation $\rightarrow$ dissolved air flotation $\rightarrow$ granular media filtration $\rightarrow$ ultrafiltration $\rightarrow$ cartridge filtration $\rightarrow$ RO

Scheme E: Open intake $\rightarrow$ coag-flocculation $\rightarrow$ dissolved air flotation $\rightarrow$ granular media filtration $\rightarrow$ cartridge filtration $\rightarrow$ RO

Scheme F: Open intake $\rightarrow$ coag-flocculation $\rightarrow$ dissolved air flotation $\rightarrow$ ultrafiltration $\rightarrow$ cartridge filtration $\rightarrow$ RO

Scheme G: Open intake $\rightarrow$ in-line coagulation $\rightarrow$ granular media filtration $\rightarrow$ cartridge filtration $\rightarrow$ RO

Scheme $\mathrm{H}$ : Open intake $\rightarrow$ in-line coagulation $\rightarrow$ ultrafiltration $\rightarrow$ cartridge filtration $\rightarrow$ RO

Scheme I: Subsurface intake $\rightarrow$ in-line coagulation $\rightarrow$ ultrafiltration $\rightarrow$ cartridge filtration $\rightarrow$ RO

Scheme J: Subsurface intake $\rightarrow$ ultrafiltration $\rightarrow$ cartridge filtration $\rightarrow$ RO

Scheme K: Subsurface intake $\rightarrow$ cartridge filtration $\rightarrow$ RO

Fig. 4. Pretreatment options and process schemes applicable for SWRO plants.

\subsection{Primary pretreatment}

\subsubsection{Coagulation}

Coagulation is commonly applied in conventional pretreatment systems, i.e., sedimentation/flotation followed by GMF to improve process performance in terms of turbidity removal and surface loading rates. Coagulation can significantly reduce the average particle size that can be removed by conventional GMF, e.g., as small as $0.2 \mu \mathrm{m}$ for well operating filters [180]. Mixing intensity and time are essential parameters in the design and operation of coagulation systems [27]. Mixing is accomplished in inline or full-scale mode. Inline coagulation is the application of a coagulant without removal of coagulated flocs through a clarification step. Inline coagulation may also be characterized by the absence of a flocculation chamber [154]. Hence, in most inline coagulation applications, coagulation is achieved by dosing the coagulant prior to a static mixer (for conventional GMF) or directly in the feed line (prior to feed pump of UF membranes). Flocculation is either achieved through inpipe flocculation or in a flocculation chamber. Flocculation may not be required in UF applications, as enlarging particle size is not an objective and pin-sized flocs are sufficient to enhance UF operation [155]. Various modes of coagulant application and subsequent processes are presented in Fig. 5.

Ferric salts, particularly ferric chloride, are the best choice for seawater coagulation [49]. While aluminium sulphate and polyaluminium chlorides (PACls) have been studied in laboratory and pilot-scale works for RO pretreatment of seawater [58], they are not used in fullscale plants. The primary reason is because of the relatively high solubility of aluminium, which could be carried over to RO membranes leading to precipitative scaling - particularly as aluminium silicate [57]. Ferric chloride is less soluble over a wider $\mathrm{pH}$ range, leaving less residual dissolved iron in the water after pretreatment and thus avoiding scaling problems. Furthermore, ferric chloride has a high ratio of cationic charge to total mass [80] that makes hydrolysis products more reactive and adsorptive with emulsified and semi-emulsified organic matter; e.g., oil and grease, natural and synthetic organic matter. The settled sludge volume of the ferric hydroxide formed from ferric chloride is reportedly
$30-60 \%$ that of sulphate based coagulants (e.g., $\left.\mathrm{Fe}_{2}\left(\mathrm{SO}_{4}\right)_{3}\right)$. Additionally, the sludge developed from ferric chloride is generally much more dewaterable [35].

\subsubsection{Sedimentation}

Sedimentation is commonly used upstream of GMF and MF/UF systems to reduce the solids load reaching these systems; typically when feed water has daily average turbidity higher than 30 NTU. For feed waters with very high turbidity ( $>100$ NTU), conventional sedimentation basins may not be adequate to produce water with low silt and algal content and enhanced solids removal may be required through e.g., lamella plate modules [180]. In the absence of sedimentation, large turbidity spikes may cause GMF to exceed their solids handling capacity, resulting in lower production capacity, shorter filter runs, frequent backwashing and poor permeate quality. Sedimentation basins for seawater pretreatment are typically designed to produce settled water of less than 2.0 NTU and SDI $_{15}$ below 6 [180]. Enhanced sedimentation technologies that combine lamella plates and fine granular media are used for feed water from open ocean intakes with high turbidity. These technologies allow for high solids removal at high rates (e.g., > $40 \mathrm{~m} / \mathrm{h})$.

\subsubsection{Dissolved air flotation (DAF)}

DAF is a clarification process that can be used to remove particles prior to conventional media filtration or MF/UF systems. Raw water is dosed with a coagulant, typically at concentrations lower than those applied for sedimentation, followed by two-stage tapered flocculation. Removal is achieved by injecting the feed water stream with water that has been saturated with air under pressure and then releasing the air at atmospheric pressure in a flotation tank. As the pressurized water is released, a large number of micro-bubbles are formed (approximately 30-100 $\mu \mathrm{m}$ ) that adhere to coagulated flocs and suspended matter causing them to float to the surface where they may be removed by either a mechanical scraper or hydraulic means, or a combination thereof. Clarified water is drawn off the bottom of the tank by a series of lateral draw-off pipes (Fig. 6). Conventional DAF systems operate at nominal 


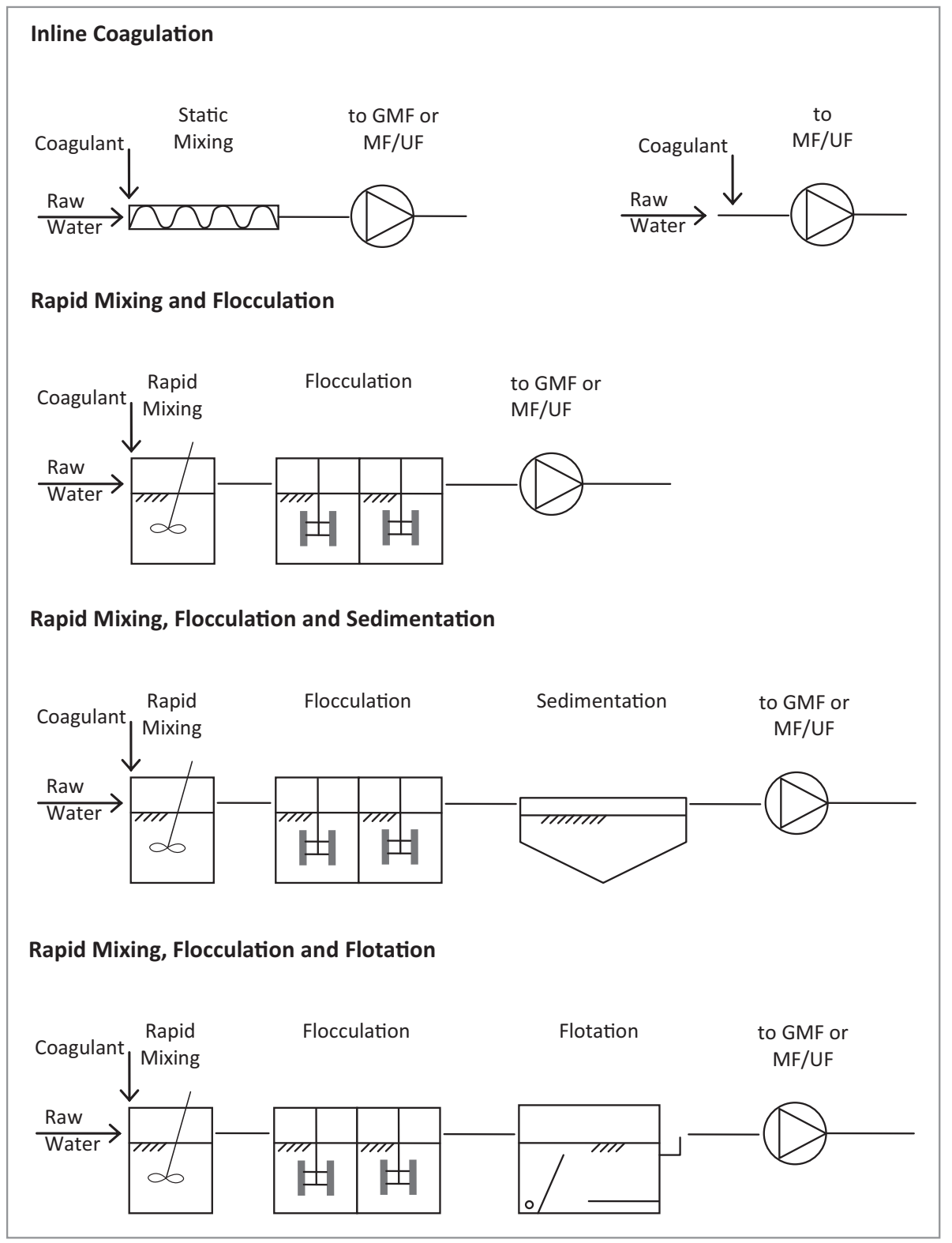

Fig. 5. Modes of coagulant application in combination with different primary and secondary processes. Adapted from [156].

hydraulic loading rates of $5-15 \mathrm{~m} / \mathrm{h}$. More recent high rate DAF units are developed for loadings of $15-30 \mathrm{~m} / \mathrm{h}$ and greater [48].

DAF is suitable for removal of low-density particles that can float, e.g., algal cells, oil and grease, which are not effectively removed by sedimentation or filtration. As such, for handling difficult waters such as algal bloom impacted seawater, incorporating DAF prior to media filtration has been proposed [10]. Flotation is able to reduce the concentration of algal cells to a large extent, protecting media filters from rapid clogging, reduced capacity, and breakthrough. A coagulant dose of 1-2 $\mathrm{mg} \mathrm{Fe}(\mathrm{III}) / \mathrm{L}$ or higher is usually required to render the process effective. Additional coagulant might be dosed just before feeding the DAF effluent to downstream granular media filters to ensure an acceptable SDI in the RO feedwater. In most DAF units, coagulation concentrations of up to $20 \mathrm{mg} / \mathrm{L}$ as $\mathrm{FeCl}_{3}$ are reported $[90,137]$. However, storm events that affect water quality may result in substantially higher coagulant concentrations for DAF [90]. Additional coagulant dosage is often required in GMF units downstream of DAF. Installing flotation units in front of media filtration might be cheaper than conventional sedimentation units, as the surface loading rates in high-rate DAF systems can reach $30 \mathrm{~m} / \mathrm{h}$ resulting in smaller footprint. However, additional equipment is required for air saturation and diffusion, treated flow recirculation, sludge skimmers, etc. all of which add to cost and complexity of the overall process.

Several DAF plants in the Netherlands and Great Britain are primarily used for treatment of algal-laden waters [64,99,169]. A review paper on separation of algae by Henderson et al. [72,73] reports DAF removals of $96 \%$ to $99.9 \%$ when pretreatment and DAF are optimised. In SWRO pretreatment, DAF prior to dual-stage GMF was tested during early pilot testing for the Taweelah SWRO plant in Abu Dhabi, UAE [137]. DAF was suggested to enhance the robustness of the pretreatment scheme in case of oil spills or HAB events, or in case high coagulant concentrations were required during turbidity spikes. Algal cell concentrations were reportedly below 100 cells/mL during this period, which is far below concentrations observed during severe bloom conditions (tens of thousands of cells per mL). Sanz et al. [140] demonstrated the effectiveness of DAF coupled with coagulation prior to dual stage GMF in producing RO feed water with SDI $<4$ (typically less than 3 ) when treating seawater containing various algae, including $\mathrm{HAB}$ species. The 


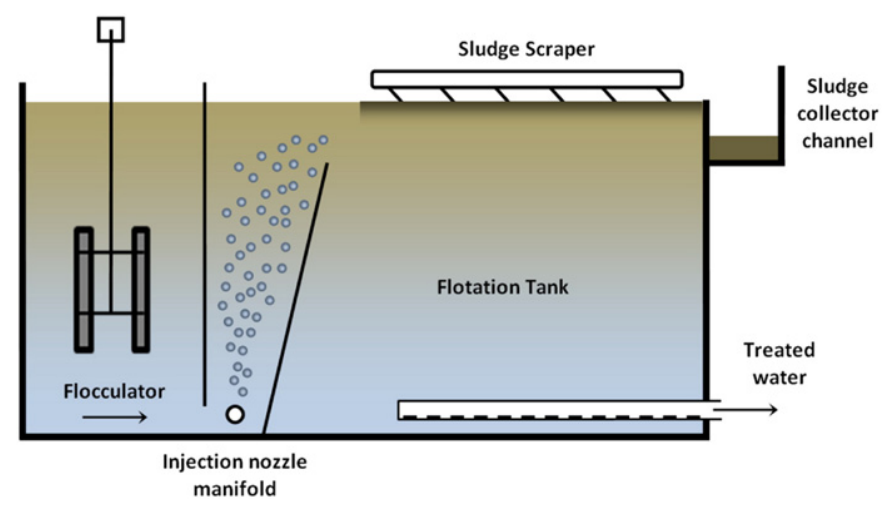

Fig. 6. Simplified schematic of a DAF unit with flocculator.

authors reported more than 99\% removal of total algae after DAF and first stage filtration units. Total cell concentration of various algal species in the feed water was not specified.

The severe HAB event in 2008-2009 in the Gulf of Oman that led to the shutdown of several desalination plants in the region redirected the attention of the desalination industry to DAF as part of SWRO pretreatment schemes. Although the Fujairah 2 desalination plant was still under construction during that period, a pilot plant fitted with a DAF unit in the pretreatment system continued to operate throughout the red tide bloom [118]. In the Al-Dur plant in Bahrain, more than 99\% removal of algal cells was reported during pilot testing of AquaDAFTM combined with coagulation prior to GMF [90]. However, significant bloom conditions were not encountered during the pilot phase with algal cell counts reaching only 200 cells $/ \mathrm{mL}$ in feed water. The AlShuwaikh desalination plant in Kuwait equipped with DAF/UF as pretreatment consistently provided $\mathrm{SDI}<2.5$ for good quality feed water and $<3.5$ for deteriorated conditions during a HAB event [120]. Bloom conditions as measured by cell counts, chlorophyll-a concentrations and/or TEP were not reported for this facility. DAF is now being regularly incorporated in new SWRO plants in the Persian Gulf upstream of GMF or MF/UF. Expansion of the Fujairah plant incorporates DAF as an essential part of the pretreatment scheme [185].

\subsection{Secondary pretreatment}

\subsubsection{Granular media filtration (GMF)}

Conventional pretreatment systems for SWRO were developed based on existing technology and most commonly consist of conventional media filtration. Single or dual stage granular media filters comprising sand and anthracite (garnet is sometimes used) are typically applied in conventional pretreatment systems, in gravity or pressurized configuration. Sand and anthracite $(0.8-1.2 \mathrm{~mm} / 2-3 \mathrm{~mm})$ filter beds are superior to single media filtration in that they provide higher filtration rates, longer runs and require less backwash water. Anthracite/ sand/garnet beds operate at normal rates of approximately $12 \mathrm{~m} / \mathrm{h}$ and peak rates as high as $20 \mathrm{~m} / \mathrm{h}$ without loss of effluent quality. In SWRO pretreatment, the primary function of GMF is to reduce high loads of particulate and colloidal matter (i.e., turbidity).

GMF relies on depth filtration to enhance RO feed water quality. However, when high concentrations of organic matter or turbidity loads are encountered, coagulation is required to ensure that RO feed water of acceptable quality is produced $(\mathrm{SDI}<5)$. Coagulation is applied either in full scale or inline mode in these systems. Coagulation aggregates particulate and colloidal matter in water and can therefore shift filtration mechanism from depth filtration to surface straining (cake filtration). As filtration rates are relatively high $(5-10 \mathrm{~m} / \mathrm{h})$ in media filters, cake filtration can result in exponential head loss in the filters.
Poor removal of algae can lead to clogging of granular media filters and short filter runs. While diatoms are well-known filter clogging algae, other algae types can clog filters including green algae, flagellates, and cyanobacteria [48]. During the severe HAB event in the Gulf of Oman and 'The Gulf' in 2008-2009, conventional pretreatment systems were not able to maintain production capacity at high algal cell concentrations of approximately 27,000 cells/mL [134]. Operation of the media filters was characterized by rapid clogging rates, deteriorating quality of pretreated water, and frequent backwashing, resulting in higher system downtime and reduced capacity $[118,141]$.

At the Fujairah plant in UAE, filter runs were reduced from 24 to $2 \mathrm{~h}$ Reducing filtration rate by $50 \%$ can lower the rate of clogging, e.g., by a factor 2-4 depending on the size and characteristics of the foulants. However, higher surface area of the media filters was required to maintain production capacity, resulting in significant investment costs and large footprint of the pretreatment system. Deteriorating quality of the pre-treated water $(\mathrm{SDI}>5)$ at this plant, led to higher coagulant dose required to enhance treated water quality. Increasing coagulant dose may lead to higher clogging rates of media filters as explained above. One way to enhance operation of GMF during such extreme events is to provide a clarification step, e.g., sedimentation or flotation after coagulation/flocculation to reduce the load of particulate/colloidal matter (including coagulated flocs) on the media filters.

The product water of granular media filters can be highly variable over time, with reported algae and biopolymer (algal-released organic macromolecules) removal efficiencies in the range of $48-90 \%$ and $17-$ $47 \%$, respectively [129,138].

\subsubsection{Ultrafiltration (UF)}

Over the last decade, UF membranes have been tested and applied at pilot and commercial scale as pretreatment for SWRO [32,60,62,68, $136,167,189]$ and are reported to offer several advantages over conventional pretreatment systems; namely, lower footprint, constant high permeate quality (in terms of SDI), higher retention of large molecular weight organics, lower overall chemical consumption, etc. [127,187]. Successful piloting has led to the implementation of UF pretreatment in several large $\left(>100,000 \mathrm{~m}^{3} /\right.$ day $)$ SWRO plants [34], e.g., Adelaide, Ashdod.

Depending on the driving force for filtration, UF membranes are divided into pressurized and vacuum-driven systems. Both outside-in and inside-out configurations are applied in SWRO pretreatment. The application of UF in SWRO pretreatment is considered a more reliable alternative to conventional GMF (with or without coagulation), as UF membranes are generally more effective in removing particulate and colloidal matter from seawater. As such, they are expected to be more reliable in producing low fouling potential RO feed water even during a HAB event. However, Voutchkov [180] reported that in a submerged vacuum-driven UF system, a driving vacuum higher than 0.4 bar can cause disruption of soft-walled algal cells resulting in the release of easily biodegradable dissolved intracellular substances which might be detrimental to the operation of downstream SWRO. So far, such issue has not been reported nor verified in pressure-driven UF systems.

To the best knowledge of the authors, there is no publicly available literature on the performance (i.e., hydraulic operation and permeate quality) of outside-in membranes in SWRO pretreatment during periods of algal bloom. From published literature, inside-out UF membranes were reported to experience some degree of fouling during algal blooms $[44,143,144]$. High concentrations of AOM present during a severe algal bloom in the North Sea impaired operation of UF membranes (Fig. 7) at a pilot desalination facility in the Netherlands, resulting in CEBs as frequent as once in $6 \mathrm{~h}$. Under such conditions, coagulant was dosed to control hydraulic performance of UF membranes $[143,144]$. With optimised inline coagulation, operation was stabilised at relatively low doses of ferric chloride $(<1 \mathrm{mg} \mathrm{Fe} / \mathrm{L})$ during the bloom period. 
Very high numbers of algal cells present in the feed water during algal blooms can adversely affect operation of inside-out UF membranes by:

- depositing along the length of the membrane capillary,

- depositing primarily at the capillary entrance, and

- depositing primarily at the capillary dead-end.

Theoretically, small particles deposit uniformly along the capillary length whereas larger particles tend to deposit primarily near the capillary dead-end $[96,117]$. This indicates that inside-out UF systems may be clogged at the capillary dead-end with algal cells and associated AOM, resulting in higher flux at the capillary inlet (assuming that the parts of the capillary with algae and AOM deposition are no longer permeable). Villacorte [172] demonstrated that, even at very high numbers, algal cell deposition does not severely limit membrane permeability. Heijman et al. [70,71] demonstrated that larger particles might plug the entrance of capillaries. However, applying microscreens with openings smaller than 150-300 $\mu \mathrm{m}$, which is the current practice, can reduce capillary plugging.

So far, a few studies have investigated the effect of algal blooms on operation of UF membranes [84,87,143,144,172]. These studies agree on the notion that large macromolecules (e.g., biopolymers such as polysaccharides and proteins) produced by algae are the main cause of membrane fouling, and more so than the algal cells as particles. AOM which comprise high molecular weight biopolymers (polysaccharides and proteins) often including sticky TEP $[109,174]$ may cause organic/particulate fouling in UF membranes. TEP can absorb/retain water by up to 99\% of their dry weight while allowing some water to pass through $[13,170]$. Consequently they can bulk-up to more than 100 times their solid volume and squeeze through and fill-up the interstitial voids between the accumulated solid particles (e.g., algal cells) on the surface of the membrane. It is therefore expected that accumulation of these materials can provide substantial resistance to permeate flow during membrane filtration. In addition, as TEP can be very sticky, they may strongly adhere to the surface and pores of UF membranes, rendering hydraulic cleaning (backwashing) ineffective (Fig. 8a). This scenario has been reported in recent studies (e.g., [130,131,143,144, $177,178]$ ), signifying that AOM does not only cause pressure increase during filtration but can also increase non-back washable or physically irreversible fouling in dead-end UF systems.
Coagulation can reduce the adverse effects of AOM on UF operation by reducing the fouling potential and compressibility of AOM layers on the membrane surface (Fig. 8b). This is mainly achieved through partial complexation of algal biopolymers and formation of colloidal Fe-biopolymer complexes at low coagulant dose $(<1 \mathrm{mg} \mathrm{Fe} / \mathrm{L})$ and adsorption of algal biopolymers onto and enmeshment in iron hydroxide precipitates forming Fe-biopolymer aggregates at coagulant dose of $1 \mathrm{mg} \mathrm{Fe} / \mathrm{L}$ and higher [157]. Coagulation of AOM - comprised mainly of hydrophilic, non-UV absorbing polysaccharides - may be governed by mechanisms that are different from coagulation of NOM (i.e., aromatic humic substances). Tabatabai [156] showed that $\mathrm{pH}$ did not play a strong role in the coagulation efficiency of AOM in terms of biopolymer removal.

Furthermore, coagulation applied in different modes can enhance the backwashability of sticky AOM layers deposited on the surface of UF membranes [156]. However, if not optimised, coagulation may deteriorate long-term UF operation. Unreacted iron species (monomers, dimers, trimers, etc.), ferrous iron and manganese - present in low-grade coagulants - can foul UF membranes by adsorbing on the membrane surface or within the pores, resulting in gradual irreversible fouling of UF membranes that will require chelation with cleaning solutions based on e.g., ascorbic and oxalic acids to release fouling.

Although extensive operational experience on HABs of different types and severities is not available, it may be proposed that insideout pressure driven UF membranes are more capable of handling HAB events than conventional GMF. This may be attributed to significant differences in hydraulic operational parameters of the two systems. An overview of operational parameters for GMF and UF is presented in Table 3. Filtration flux rates in GMF can be up to 100 times higher than flux rates in UF systems, while total filtered volume prior to backwash may be 2000 times higher. Thus, low filtration rates together with more frequent backwashing favours better UF system performance during algal blooms. Coagulation may be required to stabilise hydraulic performance of UF membranes during severe HAB events.

\section{Algal bloom indicators for quantifying pretreatment efficiency}

Monitoring membrane fouling potential of raw and pre-treated water is important in SWRO plants, especially during algal bloom periods, in order to develop preventive/corrective measures for the potential adverse impacts to RO membranes. Various indicators have been proposed to assess the magnitude of the bloom and the effectiveness of the pretreatment systems. The most relevant indicators/parameters,

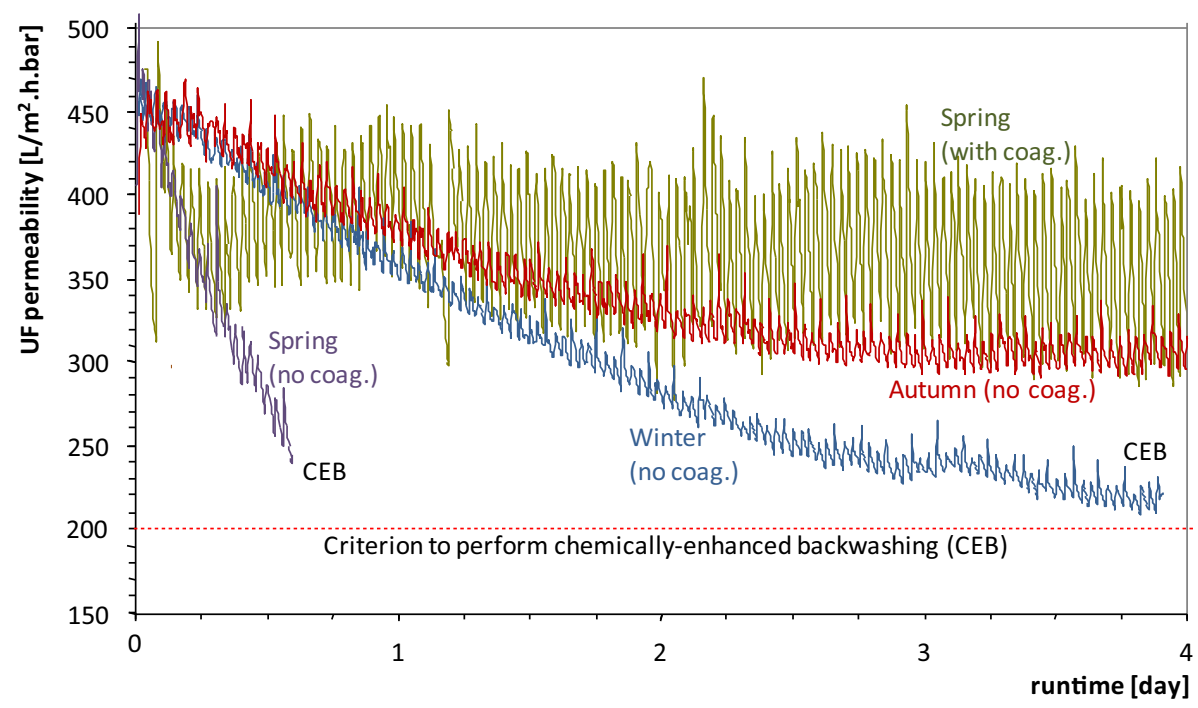

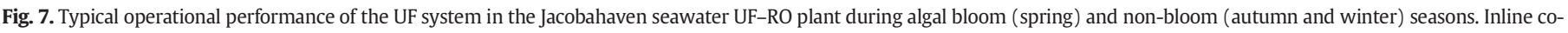
agulation pretreatment was implemented during the spring season to stabilise performance of the UF.

Graph was redrawn from Schurer et al. [143]. 


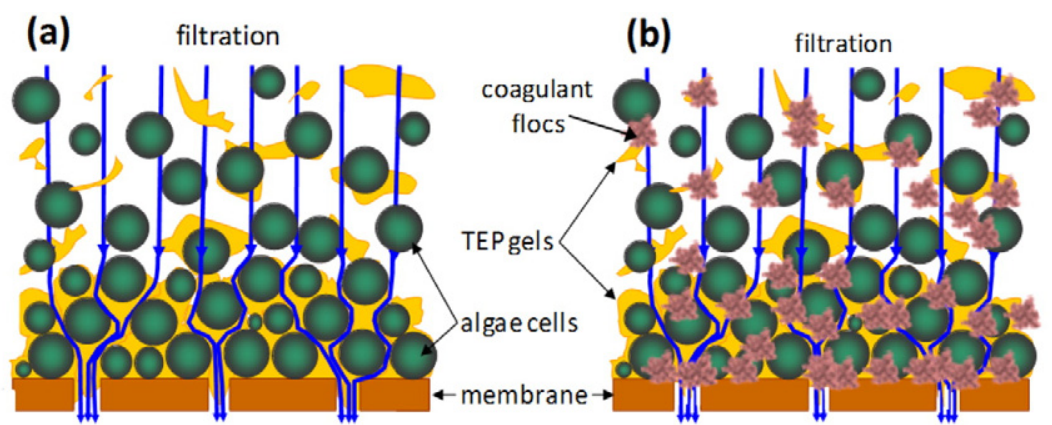

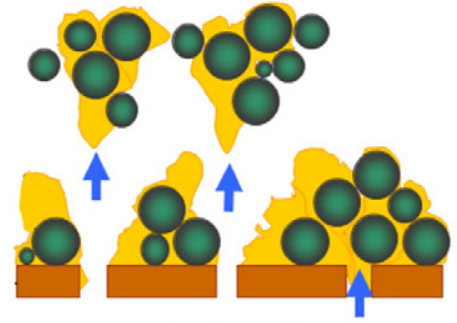

backwashing

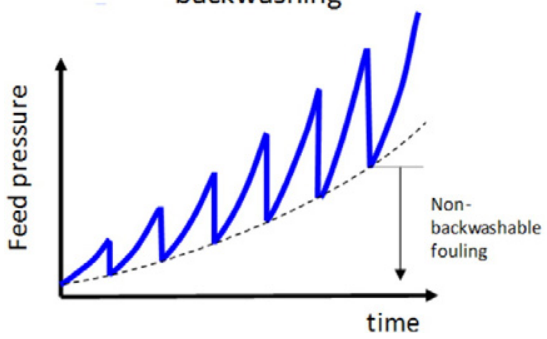

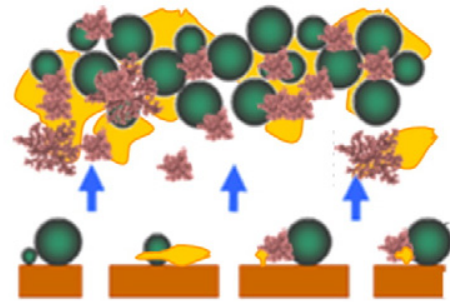

backwashing

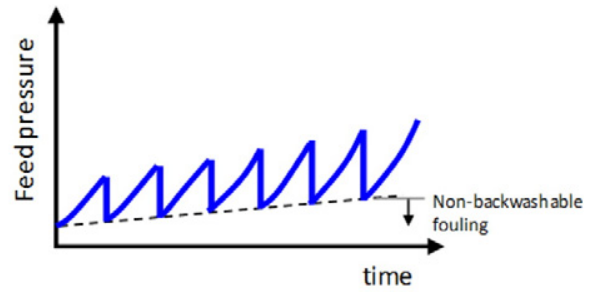

Fig. 8. Graphical presentation of membrane fouling in UF system (a) operated during severe algal blooms and (b) fouling mitigation with optimised inline coagulation.

namely: algae, biopolymer and TEP concentration and membrane fouling potential, are discussed in the following sections. A review of recent studies on the performance of various pretreatment technologies in terms of reduction of such indicators is presented in Table 4.

\subsection{Algae concentration}

The magnitude of algal blooms is usually measured either in terms of cell abundance or chlorophyll-a concentration - the former giving an indication of the relative abundance of individual species, while the later is a bulk measure that includes many different, co-occurring algal species. Bloom-forming algae of different species can vary substantially in terms of cell size and chlorophyll-a content. Hence, the relationship between these two parameters also varies. Typical bloom cell concentrations are higher for smaller algae compared with larger algae (see Table 1). To compensate for the size differences, cell concentration can be expressed in terms of volume fraction (total cell volume per volume of water sample) instead of cell number per volume of water. Operationally, this is difficult to calculate, as it requires conversion factors on the cell volume of each species that might be encountered.

Ideally, the pretreatment systems of an SWRO plant should effectively remove algal cells to prevent clogging in RO channels. As shown in Table 4, algae removals in granular media filters (GMF) are highly variable (48-90\%) as compared to more stable and much higher removal efficiencies by MF/UF membranes (>99\%). High algal removals $(>75 \%)$ were also reported for sedimentation and DAF treatments. Cartridge filters, which are typically installed after the pretreatment processes and before the SWRO system, have comparable removal with GMF.

Although algal cell and chl-a concentrations are the main indicators of an algal bloom, these parameters are not sufficient indicators of the fouling potential of the water. Different bloom-forming species of algae can behave differently in terms of AOM production and at which stage of their life cycle AOM materials are released. More advanced parameters that better indicate the concentration of $A O M$ in feed water and the fouling potential attributed to the presence of AOM are therefore necessary, some good examples of which are discussed in the succeeding sections.

\subsection{Biopolymer concentration}

AOM released by different species of algae may widely vary in terms of size and composition [73]. Recently, it has been demonstrated that the application of size exclusion chromatography, specifically liquid chromatography-organic carbon detection (LC-OCD) technique, allows the quantification of the different size and functional components of AOM in algal bloom-impacted waters [157,174,177].

LC-OCD is a semi-quantitative technique to subdivide the pool of organic matter in a water sample into six major sub-fractions which could be assigned to specific classes of compounds based on their retention time through a chromatogram column (see [76]). The high molecular

Table 3

Operational parameters for ultrafiltration and media filtration typically applied in SWRO pretreatment.

Adapted from [141].

\begin{tabular}{lll}
\hline & Ultrafiltration & Granular media filtration \\
\hline Pores $[\mu \mathrm{m}]$ & 0.02 & 150 \\
Filtration rate $\left[\mathrm{L} / \mathrm{m}^{2} \mathrm{~h}\right]$ & $50-100$ & $5000-10,000$ \\
Run length $[\mathrm{h}]$ & 1 & 24 \\
Ratio backwash rate: filtration rate & 2.5 & $2.5-5$ \\
Backwash time $[\mathrm{min}]$ & 1 & 30 \\
Filtered volume $/ \mathrm{m}^{2}$ per cycle $[\mathrm{L}]$ & $50-100$ & $120,000-240,000$ \\
Pressure loss $[\mathrm{bar}]$ & $0.2-2$ & $0.2-2$
\end{tabular}


Table 4

Reported treatment efficiencies of various treatment processes based on selected algal bloom indicators.

\begin{tabular}{|c|c|c|c|c|c|c|c|}
\hline \multirow[t]{2}{*}{ Treatment type } & \multirow[t]{2}{*}{ Water source } & \multirow[t]{2}{*}{ Treatment condition/remarks } & \multicolumn{4}{|c|}{ Reduction or removal efficiency (\%) } & \multirow[t]{2}{*}{ References } \\
\hline & & & Algae & Biopolymers & TEP & MFI-UF & \\
\hline \multicolumn{8}{|l|}{$a$} \\
\hline \multirow[t]{9}{*}{ Subsurface intake } & W. Mediterranean Sea & Beach well & & 70 & & & Salinas-Rodriguez et al. [138] \\
\hline & & Vertical beach wells & $>99$ & $\sim 100$ & $64-84$ & & Rachman et al. [132] \\
\hline & & Horizontal wells & 77 & $\sim 90$ & 34 & & Rachman et al. [132] \\
\hline & N. Pacific ocean & Infiltration gallery & & 75 & & & Salinas-Rodriguez [139] \\
\hline & Red Sea (Jeddah) & Vertical beach wells & $>99$ & $>80$ & $55-75$ & & Dehwah et al. [42] \\
\hline & & Vertical beach wells & $>99$ & $\sim 100$ & $34-65$ & & Rachman et al. [132] \\
\hline & Oman Gulf & Vertical beach wells & $>99.9$ & $>85$ & $62-70$ & & Rachman et al. [132] \\
\hline & N. Atlantic (Turks \& Caicos) & Vertical beach wells & $>99$ & $\sim 100$ & $90-92$ & & Rachman et al. [132] \\
\hline & N. Atlantic (Canary Is.) & Well intake & 100 & & & & Teuler et al. [163] \\
\hline \multirow{8}{*}{$\begin{array}{l}\text { Dissolved air } \\
\text { flotation }\end{array}$} & W. Mediterranean Sea & Coag. $=0-6 \mathrm{mg} \mathrm{FeCl}_{3} / \mathrm{L}$ & 75 & & & & Guastalli et al. [65] \\
\hline & Lake water & Coag. $=7-12 \mathrm{mg} \mathrm{Fe}^{3+} / \mathrm{L}$ & 96 & & & & Vlaski [179] \\
\hline & River water (Meuse) & Coag. $=4 \mathrm{mg} \mathrm{Fe}^{3+} / \mathrm{L}$ & & $>70$ & $>70$ & 86 & Villacorte [172] \\
\hline & Algae-spiked freshwater & Coag. $=12 \mathrm{mg} \mathrm{Al}_{2} \mathrm{O}_{3} / \mathrm{L}$ & 96 & & & & Teixeira \& Rosa [159] \\
\hline & & Coag. $=0.5-4 \mathrm{mg} \mathrm{Al}_{2} \mathrm{O}_{3} / \mathrm{L}$ & $90-100$ & & & & Teixeira et al. [160] \\
\hline & Algal culture (saline water) & Coag. $=60 \mathrm{mg} \mathrm{FeCl}_{3} / \mathrm{L}$ & $58-90$ & & & & Zhu et al. [192] \\
\hline & & Coag. $=90 \mathrm{mg} \mathrm{FeCl}_{3} / \mathrm{L}$ & $87-93$ & & & & Zhu et al. [192] \\
\hline & Algal culture (freshwater) & Coag. $=0.7-3 \mathrm{mg} \mathrm{Al} / \mathrm{L}$ & 98 & & & & Henderson et al. [74] \\
\hline \multirow[t]{6}{*}{ Sedimentation } & Lake water & Coag. $=20-24 \mathrm{mg} \mathrm{Fe}^{3+} / \mathrm{L}$ & 96 & & & & Vlaski [179] \\
\hline & Algae-spiked freshwater & Coag. $=12 \mathrm{mg} \mathrm{Al}_{2} \mathrm{O}_{3} / \mathrm{L}$ & 90 & & & & Teixeira \& Rosa [159] \\
\hline & Algal cultures & No coagulation & & 12 & & & Tabatabai et al. [157] \\
\hline & & Coag. $=0.5 \mathrm{mg} \mathrm{Fe}^{3+} / \mathrm{L}$ & & 32 & & & Tabatabai et al. [157] \\
\hline & & Coag. $=5 \mathrm{mg} \mathrm{Fe}^{3+} / \mathrm{L}$ & & 75 & & & Tabatabai et al. [157] \\
\hline & & Coag. $=10 \mathrm{mg} \mathrm{Fe}^{3+} / \mathrm{L}$ & & 80 & & & Tabatabai et al. [157] \\
\hline$b$ & & & & & & & \\
\hline Granular media & E. Mediterranean Sea & Rapid sand filter (no coag.) & $76 \pm 13$ & & $51 \pm 27$ & & Bar-Zeev et al. [18] \\
\hline filtration & & Coag. + mixed bed filter & $90 \pm 8$ & & $27 \pm 19$ & & Bar-Zeev et al. [19] \\
\hline & & Coag. $\left(1 \mathrm{mg} \mathrm{Fe}_{2}\left(\mathrm{SO}_{4}\right)_{3}\right)+\mathrm{RSF}$ & $79 \pm 8$ & & $17 \pm 28$ & & Bar-Zeev et al. [17] \\
\hline & & Coag. + single media filter & & 32 & & & Salinas-Rodriguez et al. [138] \\
\hline & W. Mediterranean Sea & Press. GMF (anthracite-sand) & 74 & 18 & & & Guastalli et al. [65] \\
\hline & & Coag. + dual media filter & & 47 & & & Salinas-Rodriguez et al. [138] \\
\hline & & Anthracite-sand; $1.5 \mathrm{mg} \mathrm{Fe}^{3+} / \mathrm{L}$ & & & & 19 & Salinas-Rodriguez [139] \\
\hline & N. Mediterranean Sea & Anthracite-sand; $2 \mathrm{mg} \mathrm{Fe}^{3+} / \mathrm{L}$ & & & & 37 & Salinas Rodriguez [139] \\
\hline & Estuarine (brackish) & Coag. + continuous sand filter & & 17 & 65 & & Salinas-Rodriguez et al. [138] \\
\hline & Algae-spiked seawater & Dual media filter (no coag.) & $48-90$ & & & & Plantier et al. [129] \\
\hline & River water & Coag. $(8 \mathrm{ml} \mathrm{PACl} / \mathrm{L})+\mathrm{RSF}$ & & & 25 & & Villacorte et al. [175] \\
\hline & & Rapid sand filter (no coag.) & & & $\sim 100$ & & van Nevel et al. [168] \\
\hline & Treated wastewater & Coag. $\left(10 \mathrm{mg} \mathrm{Al}^{3+} / \mathrm{L}\right)+\mathrm{RSF}$ & & & 70 & & Kennedy et al. [82] \\
\hline Sedimentation + & Lake water & Coag. $\left(15 \mathrm{mg} \mathrm{Fe}^{3+} / \mathrm{L}\right)+$ sand filt. & & & 70 & & Villacorte et al. [175] \\
\hline filtration & Algal culture & Coag. $\left(0.5 \mathrm{mg} \mathrm{Fe}^{3+} / \mathrm{L}\right)+0.45 \mu \mathrm{m}$ & & 45 & & & Tabatabai et al. [157] \\
\hline & & Coag. $\left(5 \mathrm{mg} \mathrm{Fe}^{3+} / \mathrm{L}\right)+0.45 \mu \mathrm{m}$ & & 77 & & & Tabatabai et al. [157] \\
\hline & & Coag. $\left(10 \mathrm{mg} \mathrm{Fe}^{3+} / \mathrm{L}\right)+0.45 \mu \mathrm{m}$ & & 85 & & & Tabatabai et al. [157] \\
\hline Micro-/Ultra-filtration & W. Mediterranean Sea & PVDF; nom. pore size $=0.1 \mu \mathrm{m}$ & & 36 & & & Salinas-Rodriguez et al. [138] \\
\hline (MF/UF) & & PVDF membrane & & 14 & & & Salinas-Rodriguez [139] \\
\hline & & PVDF; pore size $=0.02 \mu \mathrm{m}$ & 99 & 41 & & & Guastalli et al. [65] \\
\hline & & PVDF, $0.03 \mu \mathrm{m}$ & & & & 66 & Salinas-Rodriguez [139] \\
\hline & & PVDF, $0.02 \mu \mathrm{m}$ & & & & 52 & Salinas-Rodriguez [139] \\
\hline & N. Mediterranean Sea & PVDF; $0.01 \mu \mathrm{m}$ & & & & 68 & Salinas-Rodriguez [139] \\
\hline & Red Sea & Ceramic; pore size $=0.08 \mu \mathrm{m}$ & & 20 & & & Dramas and Croué [47] \\
\hline & & Ceramic; pore size $=0.03 \mu \mathrm{m}$ & & 40 & & & Dramas and Croué [47] \\
\hline c & & & & & & & \\
\hline Micro-/ultra-filtration & Oman Gulf & Ceramic; pore size $=0.08 \mu \mathrm{m}$ & & 30 & & & Dramas \& Croué [47] \\
\hline (MF/UF) (cont'd.) & North Sea & PES $300 \mathrm{kDa} 0.5 \mathrm{mg} \mathrm{Al}^{3+} / \mathrm{L}$ & & 50 & & 88 & Salinas-Rodriguez [139] \\
\hline & Seawater (Sydney) & $\mathrm{MWCO}=17.5 \mathrm{kDa}$ & & 81 & & & Naidu et al. [110] \\
\hline & Algae-spiked seawater & Ceramic; pore size $=0.03 \mu \mathrm{m}$ & & 60 & & & Dramas \& Croué [47] \\
\hline & Estuarine (brackish) & No coagulation & & 70 & 100 & & Salinas-Rodriguez et al. [138] \\
\hline & Algae-spiked freshwater & PVC; nom. pore size $=0.01 \mu \mathrm{m}$ & 100 & & & & Zhang et al. [191] \\
\hline & Algal cultures & PC; nom. pore size $=0.1 \mu \mathrm{m}$ & & $52-56$ & & & Villacorte et al. [174] \\
\hline & & No coagulation & $>99$ & & & & Castaing et al. [37] \\
\hline & & PES; $\mathrm{MWCO}=100 \mathrm{kDa}$ & & $65-83$ & & & Villacorte et al. [174] \\
\hline & & $\mathrm{RC} ; \mathrm{MWCO}=10 \mathrm{kDa}$ & & $83-95$ & & & Villacorte et al. [174] \\
\hline & & No coagulation & & 45 & & & Tabatabai et al. [157] \\
\hline & & Coag. $=0.5 \mathrm{mg} \mathrm{Fe}^{3+} / \mathrm{L}$ & & 77 & & & Tabatabai et al. [157] \\
\hline & & Coag. $=5 \mathrm{mg} \mathrm{Fe}^{3+} / \mathrm{L}$ & & 83 & & & Tabatabai et al. [157] \\
\hline & & Coag. $=10 \mathrm{mg} \mathrm{Fe}^{3+} / \mathrm{L}$ & & 85 & & & Tabatabai et al. [157] \\
\hline & Lake water & 300 kDa MWCO & & & 100 & & Villacorte et al. [175] \\
\hline & River water & PVDF; pore size $=0.02 \mu \mathrm{m}$ & & 86 & & & Hallé et al. [66] \\
\hline & & PVDF; pore size $=0.01 \mu \mathrm{m}$ & & 59 & & & Huang et al. [75] \\
\hline & & Coag. $=3 \mathrm{mg} \mathrm{Fe}^{3+} / \mathrm{L}$ & & & 100 & & Villacorte et al. [175] \\
\hline & & Coag. $=0.3 \mathrm{mg} \mathrm{Fe}^{3+} / \mathrm{L}$ & & & 100 & & Villacorte et al. $[175,176]$ \\
\hline
\end{tabular}


Table 4 (continued)

\begin{tabular}{|c|c|c|c|c|c|c|c|}
\hline \multirow[t]{2}{*}{ Treatment type } & \multirow[t]{2}{*}{ Water source } & \multirow[t]{2}{*}{ Treatment condition/remarks } & \multicolumn{4}{|c|}{ Reduction or removal efficiency (\%) } & \multirow[t]{2}{*}{ References } \\
\hline & & & Algae & Biopolymers & TEP & MFI-UF & \\
\hline \multirow{3}{*}{ Cartridge filters } & E. Mediterranean Sea & Disruptor@ media & 60 & & 59 & & Komlenic et al. [85] \\
\hline & Lake Kinneret & Amiad ${ }^{\mathrm{TM}}$ AMF; $2-20 \mu \mathrm{m}$ & $90 \pm 6$ & & $47 \pm 21$ & & Eschel et al. [50] \\
\hline & River Jordan & Disruptor@ media & 85 & & 82 & & Komlenic et al. [85] \\
\hline
\end{tabular}

weight fractions are classified as biopolymers. When coupled with an organic nitrogen detector (OND), this fraction can be further divided to estimate the polysaccharide and protein components. The low molecular weight fractions $(<1 \mathrm{kDa})$ are sub-classified into humic-like substances, building blocks, low molecular weight acids, and neutrals. Considering that the high molecular weight AOM are likely to deposit/accumulate in the RO system, measuring the biopolymer fraction of organic matter in the water is a promising indicator of organic and biological fouling potential of algal bloom impacted waters. Although not proven via LC-OCD analysis, one would expect biodegradable/assimilable low molecular weight acids to contribute to the biological fouling as well. However, a recent study showed that algal-derived organic material extracted from 3 species of bloomforming algae mainly comprise biopolymers $(>50 \%)$ while some species also produce substantial amounts of refractory low molecular weight organic compounds which is considered not readily biodegradable $[172,174]$.

As shown in Table 4, biopolymers in seawater can be totally removed through sub-surface intake (specifically vertical beach wells) treatment but substantial removals $(>50 \%)$ by UF and coagulationsedimentation-filtration were reported as well. Coagulation followed by granular media filtration typically removes less than $50 \%$. Although very limited information is available regarding biopolymer removal by DAF, removal of more than $70 \%$ was reported in freshwater [172].

\subsection{TEP concentration}

TEPs are a major component of the high molecular weight fraction (biopolymers) of AOM. As discussed in previous sections, these materials are potentially a major cause of organic fouling in UF and biological fouling in RO systems. Over the last two decades, various methods have been developed to measure TEP by microscopic enumeration [4] or by spectrophometric measurements $[12,124,164,173]$. The most widely used and accepted method was introduced in 1995 by Passow and Alldredge. This method was based on retention of TEP on $0.4 \mu \mathrm{m}$ polycarbonate membrane filters and subsequent staining with Alcian blue dye. The reported TEP reduction by different pretreatment processes based on this method are summarised in Table 4. MF/UF can completely remove TEP while subsurface intake systems, GMF, DAF and cartridge filters can remove $34-92 \%, 17-100 \%$, $>70 \%$ and $47-82 \%$ of TEP, respectively.

Although they are operationally defined as particles larger than $0.4 \mu \mathrm{m}$, TEPs are not solid particles, but rather agglomeration of particulate and colloidal hydrogels which can vary in size from few nanometres to hundreds of micrometres $[121,170]$. Hydrogels are highly hydrated and may contain more than $99 \%$ of water, which means they can bulkup to more than 100 times their solid volume $[13,170]$. A majority of these materials are formed abiotically through spontaneous assembly of colloidal polymers from algae known as TEP precursors [39,121]. These submicron precursors $(<0.4 \mu \mathrm{m})$, which have similar chemical properties with TEP but not covered by the current established method (i.e., [124]), may agglomerate and form TEP in the RO system after passing through the pretreatment system. Recently, an improved TEP method was developed to cover this previously neglected colloidal fraction and allow better measurement of the efficiency of the pretreatment processes in preventing TEP fouling in RO membranes [173].

\subsection{Particulate/organic fouling potential}

There are two established methods to measure the particulate/organic fouling potential of RO feed water, namely; the silt density index (SDI) and the modified fouling index (MFI). Currently, the SDI is the most widely used method to measure the fouling potential of the feed water in SWRO plants. It is based on measurements using membrane filters with 0.45 micrometre pores at a pressure of $210 \mathrm{kPa}$ (30 psi). $\mathrm{Al}$ though this simple technique is currently widely used in practice, it has been known for many years that SDI has no reliable correlation with the concentration of particulate/colloidal matter [2]. Hence, it is often insufficient in predicting the fouling potential of SWRO feed water.

A more reliable approach to measure the membrane fouling potential of RO feed water is the modified fouling index (MFI). Unlike SDI, MFI is based on a known membrane fouling mechanism (i.e., cake filtration). This index was developed by Schippers and Verdouw [142] whereby they demonstrated the linear correlation between the MFI and colloidal matter concentration in the water. Initially, MFI was measured using membranes with 0.45 or $0.05 \mu \mathrm{m}$ pore sizes and at constant pressure. However, it was later found that particles smaller than the pore size of these membranes most likely play a dominant role in particulate fouling. In addition, it became clear that the predictive value of MFI measured at constant pressure was limited. For these reasons, MFI test measured at constant flux with ultra-filtration membranes (MFI-UF) was eventually developed over the last decade [29,30,193]. A comparison of the reduction of fouling potential as measured by MFI-UF in pretreatment systems is presented in Table 4. In general, UF membranes are superior over GMF in terms of MFI-UF reduction.

\subsection{Biological fouling potential index}

Measuring biological fouling potential of RO feed water is rather complicated. Over the years, multiple parameters have been proposed as indicators of biofouling potential, namely: adenosine triphosphate (ATP), assimilable organic carbon (AOC) and biodegradable dissolved organic carbon (BDOC) [5,182]. So far, these parameters are mainly applied in non-saline waters and still not extensively used in seawater RO plants. Furthermore, inline monitors such as the biofilm monitor and membrane fouling simulator (MFS) have been introduced to measure biofilm formation rate [182,183]. Meanwhile, Liberman and Berman [98] proposed a set of tests to determine the microbial support capacity of water samples, namely chlorophyll-a, TEP, bacterial activity, total bacterial count, inverted microscope observations of settled water samples, biological oxygen demand (BOD), total phosphorous and total nitrogen. Further investigations are needed to assess the reliability of these parameters/monitors to predict the biofouling potential of algal bloom impaired seawater.

\section{Strategies to control operational issues in SWRO plants during algal blooms}

Regardless of their location, SWRO plants can be adversely affected by algal blooms (see Figs. 2 and 9). Therefore, it is important to establish a robust monitoring programme to measure potential impact of algal blooms and to assess the effectiveness of the pretreatment system in 
preventing fouling in SWRO. Measurement of algal bloom indicators (see Section 5.0) can be performed on a routine basis and with higher frequency in seasons when algal blooms are historically known to occur. For instance, in the Gulf of Oman, algal blooms typically occur during the period of January to April and August to September while algal bloom occurrences in the Arabian Sea only peaks during August to October [1]. In the absence of historical records, it is important to perform continuous monitoring during the pilot testing phase to properly design the SWRO plant to continuously operate during algal blooms. Large-scale HAB phenomena off-shore can be monitored using satellite optical sensors coupled with numerical models to forecast the transport and landfall of such blooms [153,190]. Such application is still subject to intensive research and verification but it does have a good potential in developing an early warning system for SWRO desalination plants.

Although the presence of HAB toxins in seawater does not pose a major operational issue in SWRO plants, the possibility of potent toxins reaching the drinking water system (even at low concentrations) can be a major public health issue or may influence greatly the perception of the public regarding the safety of desalinated water. Boerlage and Nada [28] recommended that drinking water SWRO plants should develop a water safety plan (WSP) to define critical control point for algal toxin monitoring. The WSP should include continuous measurement of conductivity (salt rejection surrogate) in desalinated water to monitor the integrity of SWRO process in removing toxins.

Following the 2008-2009 HAB outbreak in the Gulf of Oman, an expert workshop was held in Oman on the impact of Red Tides and HABs on desalination operation. During this workshop, DAF and UF were highly recommended as possible alternatives to GMF for maintaining reliable operation in RO plants during severe algal bloom situations [10]. Moreover, installing a sub-surface intake (e.g., beach wells) instead of an open intake is increasingly being considered as a pretreatment option for SWRO.

SWRO plants operating with sub-surface intakes, especially vertical beach wells, are less vulnerable to HABs as these intakes can serve as natural (slow) sand filters which can substantially enhance removal of algae, bacteria and AOM from raw water entering SWRO plants due to long retention time [105]. Consequently, less-extensive pretreatment processes are needed to maintain stable operation in the SWRO plant. However, sub-surface intakes may not be applicable in some coastal locations where the geology of the area (e.g., high mud content sediments, low permeability rocks) makes it unfeasible to install such structures due to high energy costs.

SWRO plants operating with direct/open source intake require extensive pretreatment of the raw water to maintain or prolong reliable performance and membrane life. As such, primary and secondary pretreatment systems are installed to ensure acceptable RO feed water quality and stable operation during algal blooms. Primary pretreatment typically includes microstraining/screening to remove large suspended materials ( $>50 \mu \mathrm{m}$ ), coagulation and clarification by sedimentation or DAF. Secondary pretreatment typically comprises (dual) GMF or UF.

A reliable pretreatment system is one that can continuously produce high quality RO feed water while maintaining stable hydraulic operation. In GMF and UF pretreatment systems, stable operation is the ability of the system to maintain acceptable backwash frequency at minimum chemical and energy requirement. GMF might require full-scale coagulation/flocculation followed by clarification to ensure high quality RO feed water and stable hydraulic operation. A flocculation basin or floc removal step may not necessarily be required in UF pretreatment systems. Schurer et al. [144] demonstrated that UF operation could be stabilised during algal blooms when preceded by in-line coagulation without flocculation or clarification. Other operational measures such as decreasing membrane flux and applying a forward flush cleaning may also improve the performance of UF during severe algal bloom situations. These measures in turn translate into higher required filtration area (larger overall footprint) and lower productivity of the UF membranes.

Pre-coating UF membranes with a layer of pre-formed flocs of ferric hydroxide at the start of each filtration cycle, intermittent coating and intermittent coagulation have all shown to be promising approaches in controlling UF hydraulic performance during algal bloom periods with low chemical requirements [156]. Combining such dosing strategies with new generation of UF membranes with low molecular weight cut-off [174] may ensure the production of high quality RO feed water with very low coagulant consumption.

\section{Future pretreatment challenges}

Currently, biofouling and the associated chemical cleaning of membranes is a major challenge to the cost-effective application of SWRO technology, especially in HAB-prone areas. High cleaning frequencies make RO systems less reliable/robust, i.e., longer downtime and increased risk of membrane damage. This is in particular a concern for large plants. Driven by the increasing global demand as well as the economy of scale on the cost of desalinated water, it is projected that more large-scale RO plants $\left(>500,000 \mathrm{~m}^{3} /\right.$ day) will be installed in the near future (Fig. 10). A mega-size SWRO plant, with production capacity of 1 million $\mathrm{m}^{3} /$ day, is expected to be completed by year 2020 [86]. If pretreatment systems in these plants are ineffective during HABs, they will likely result to severe organic/biological fouling, which often requires extensive chemical cleanings (i.e., CIP) and premature membrane replacement, leading to high operational costs for such plants. Moreover, plant operators may be charged with penalties if they fail to supply the contracted amounts of water. Consequently, for current and future large and extra-large SWRO plants, it is essential that pretreatment systems are reliable in maintaining RO feed water with very low fouling potential. The increasing number of SWRO plants equipped with UF as pretreatment reflects this expectation.

To minimise the cleaning frequency of SWRO plants affected by algal blooms, the development of a new generation of pretreatment technology should focus on complete removal of algae and their AOM as well as limiting the concentration of nutrients in RO feed water. Removal of algae and AOM (e.g., TEP) in itself can eliminate organic fouling and may substantially delay the onset of biological fouling in SWRO as there would be a minimal "conditioning layer" to jump-start biofilm development and reduced biodegradable carbon as a microbial nutrient. On the other hand, removal of essential nutrients (e.g., phosphate, dissolved AOC) from the RO feed water can further control biological growth in the system $[78,79,181]$. Integrating the two treatment strategies can delay and potentially eliminate organic/biological fouling in seawater RO systems, even in severe HAB situations.

\section{Summary and outlook}

Virtually every coastal country in the world can be affected by algal blooms. This phenomenon is mainly triggered by natural processes but human activities have been reported to increase their frequency and severity as well. The recorded algal cell size, cell density and potential consequences during algal blooms can vary substantially, owing mainly to the high diversity of the causative species. Some types of blooms are considered harmful because of their capability to produce toxins and/ or their tendency to proliferate in dense concentrations. Toxic and non-toxic HABs produce varying concentrations and types of algal organic matter (AOM) which are either actively exuded by living algal cells and/or released through lyses of compromised cells. A major component of AOM is highly sticky (e.g., TEP) and has been identified as a major initiator and/or promoter of biofilm in marine aquatic environments.

Recent severe HAB outbreaks in the Middle East have resulted in temporary closure of multiple seawater desalination installations in the region, mainly due to breakdown of pretreatment systems and/or 


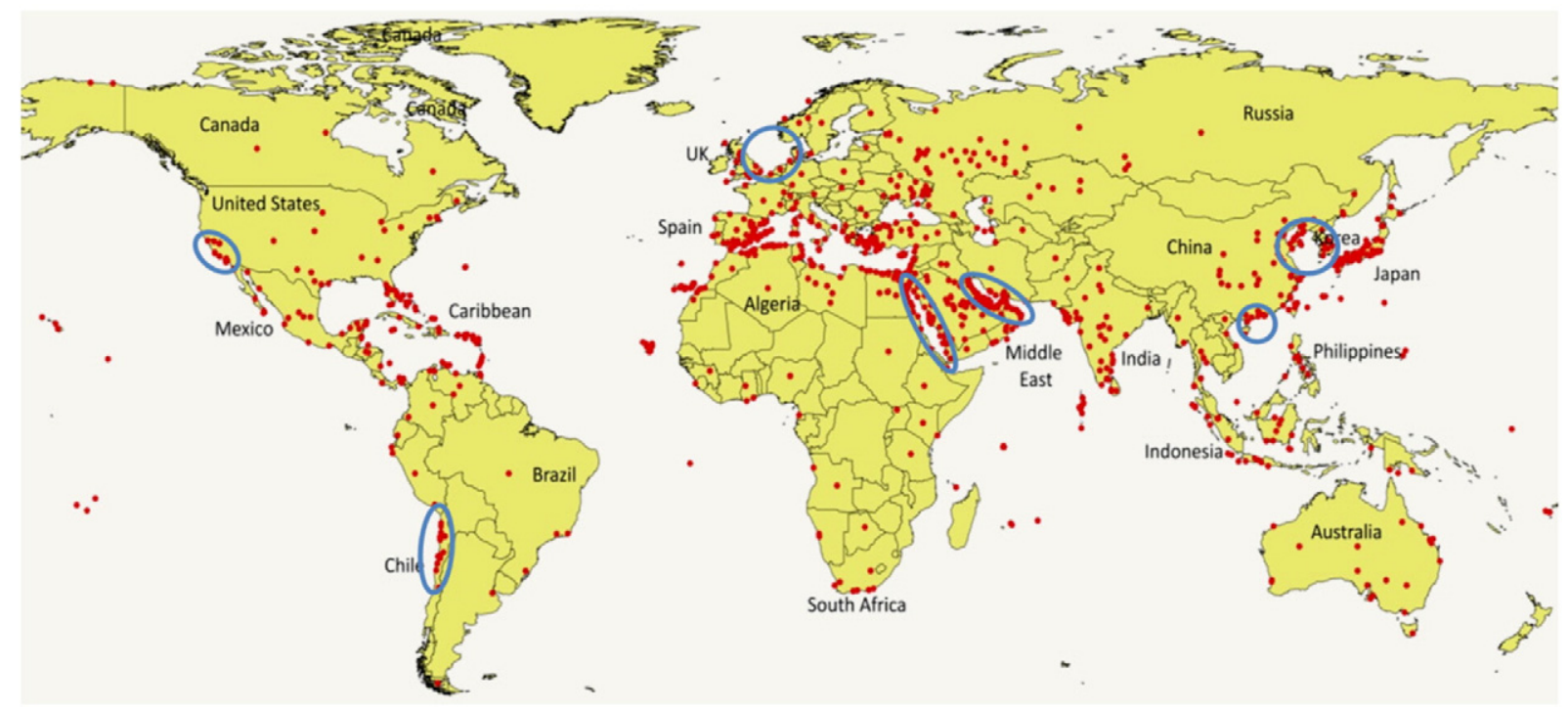

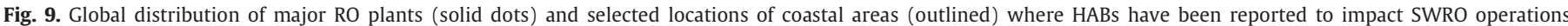

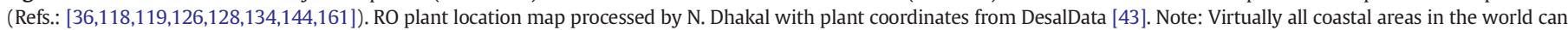
be affected by HABs, so it is likely that HABs have affected or will affect SWRO operations in areas that are not outlined on the map or documented in the literature.

as a drastic measure to prevent irreversible biofouling problems in SWRO membranes downstream. The major specific issues which may occur in SWRO plants during an algal bloom are: (1) particulate/organic fouling of pretreatment systems (e.g., GMF, MF/UF) by algal cells, their detritus and/or AOM, and (2) biological fouling of NF/RO initiated and/or enhanced by AOM. The presence of HAB toxins in desalinated water is a potential concern, but only at very low concentrations considering the $>99 \%$ removal capability of SWRO membranes. As membranebased desalination is expected to grow in terms of production capacity and global application, many coastal areas in the world will potentially face a similar scenario in the future if these $\mathrm{HAB}$-associated problems are not adequately addressed.

To tackle serious operational problems of membrane-based desalination plants, a number of pretreatment strategies are currently being proposed. For areas frequently affected by algal blooms, a monitoring programme should be established to measure indicators (e.g., algae,
MFI-UF, TEP) of their impact and to assess the effectiveness of the pretreatment system in preventing (bio)fouling in SWRO. When geological conditions are favourable, subsurface intake can serve as a robust pretreatment to protect SWRO plants from the direct impact of algal blooms. Existing SWRO plants with open intake and are fitted with conventional granular media filtration can gain significant benefits in terms of capacity and product water quality if preceded by DAF or sedimentation. As a consequence, coagulant consumption will increase as a result of coagulant dosage prior to DAF or sedimentation. Therefore, particularly in countries with stringent legislation, such schemes should include sludge handling and/or treatment facilities.

If conditions allow, UF pretreatment (with inline coagulation) should be incorporated in the SWRO plant design, either as a one step process or as a secondary pretreatment. To minimise risk of operational failure in the pretreatment system during HABs, the second option is preferred, whereby UF is preceded by DAF or sedimentation or

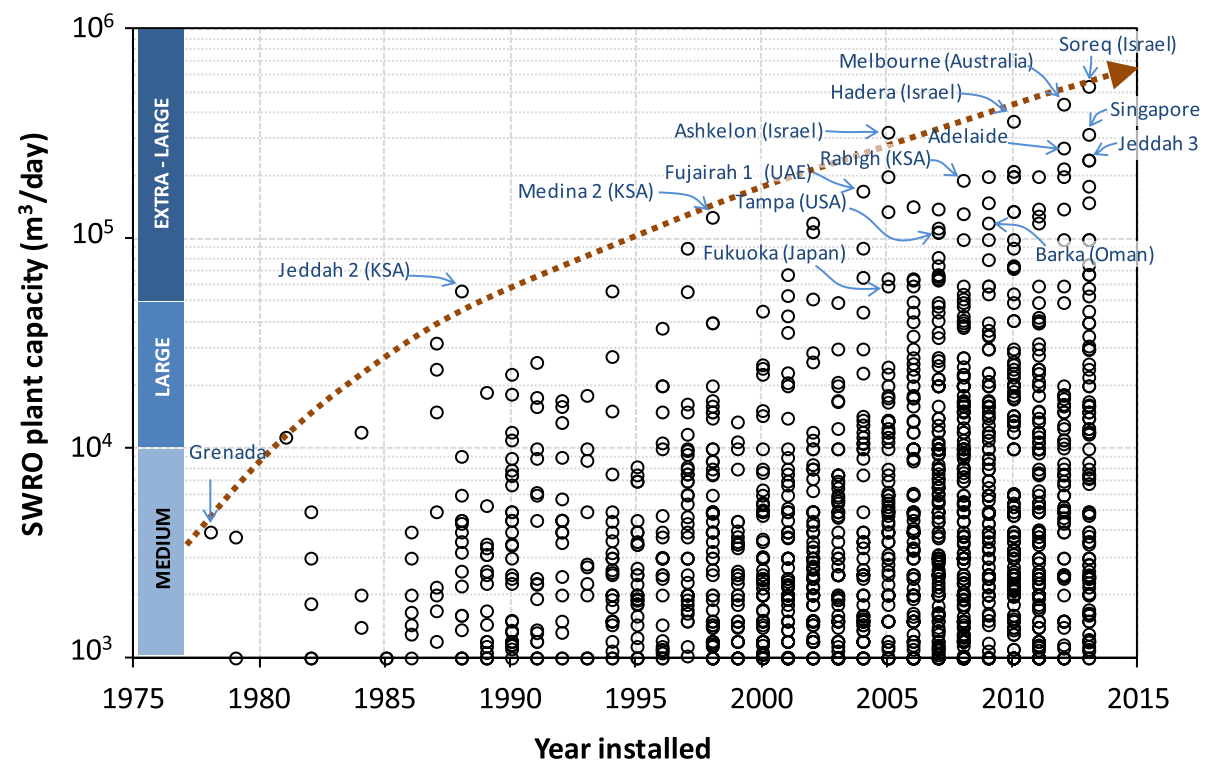

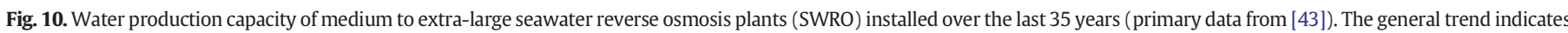
that the largest plant by year 2020 will have a capacity close to a mega-size plant of 1 million $\mathrm{m}^{3} /$ day. 
subsurface intake. Significant benefits of UF pretreatment can be gained during periods of severe HABs in terms of maintaining pretreatment capacity and RO feed water quality. Moreover, coagulant consumption is significantly lower in these systems compared to conventional pretreatment systems. The future of UF pretreatment for SWRO lies in the development of tight UF membranes (low MWCO) which can completely remove AOM during bloom periods and deliver high quality RO feed water (very low SDI or MFI-UF) at minimal coagulant consumption and high output rates.

\section{Acknowledgements}

This study was conducted with the financial support of UNESCO-IHE Institute for Water Education, Wetsus Centre of Excellence for Sustainable Water Technology and Water Desalination and Reuse Center (KAUST, Saudi Arabia). Support for D. M. Anderson was provided through the Woods Hole Center for Oceans and Human Health, National Science Foundation Grant OCE-1314642 and National Institute of Environmental Health Sciences Grant 1-P01-ES021923-01.

\section{References}

[1] A. Al-Azri, S. Piontkovski, K. Al-Hashmi, H. Al-Gheilani, H. Al-Habsi, S. Al-Khusaibi, $\mathrm{N}$. Al-Azri, The occurrence of algal blooms in Omani coastal waters, Aquat. Ecosyst. Health Manag. 15 (1) (2012) 56-63.

[2] A. Alhadidi, B. Blankert, A.J.B. Kemperman, R. Schurer, J.C. Schippers, M. Wessling W.G.J. van der Meer, Limitations, improvements and alternatives of the silt density index, Desalin. Water Treat. 51 (4-6) (2013) 1104-1113.

[3] A.L. Alldredge, M.W. Silver, Characteristics, dynamics and significance of marine snow, Prog. Oceanogr. 20 (1) (1988) 41-82.

[4] A.L. Alldredge, U. Passow, B.E. Logan, The abundance and significance of a class of large, transparent organic particles in the ocean, Deep-Sea Res. I 40 (1993) $1131-1140$.

[5] G.L. Amy, S.G. Salinas-Rodriguez, M.D. Kennedy, J.C. Schippers, S. Rapenne, P.J Remize, C. Barbe, C.L.D.O. Manes, N.J. West, P. Lebaron, D. van der Kooij, H. Veenendaal, G. Schaule, K. Petrowski, S. Huber, L.N. Sim, Y. Ye, V. Chen, A.G. Fane, Water quality assessment tools, in: E. Drioli, A. Criscuoli, F. Macedonio (Eds.), Membrane-based Desalination - An Integrated Approach (MEDINA), IWA Publishing, New York, 2011, pp. 3-32.

[6] C.R. Anderson, M.R.P. Sapiano, M.B.K. Prasad, W. Long, P.J. Tango, C.W. Brown, R. Murtugudde, Predicting potentially toxigenic Pseudo-nitzschia blooms in the Chesapeake Bay, J. Mar. Syst. 83 (2010) 127-140.

[7] D.M. Anderson, P.M. Glibert, J.M. Burkholder, Harmful algal blooms and eutrophication: nutrient sources, composition, and consequences, Estuaries 25 (2002) 704-726.

[8] D.M. Anderson, Toxic algal blooms and red tides: a global perspective. pp. 11-16 in: T. Okaichi, D.M. Anderson, T. Nemoto (Eds.), Red Tides: Biology, Environmental Science and Toxicology, Elsevier, New York, Amsterdam, London, 1989.

[9] D.M. Anderson, HABs in a changing world: a perspective on harmful algal blooms, their impacts, and research and management in a dynamic era of climactic and environmental change, in: H.G. Kim, B. Reguera, G. Hallegraeff, C.K. Lee, M.S. Han, J.K. Choi (Eds.), Harmful Algae 2012, Proceedings of the 15th International Conference on Harmful Algae, International Society for the Study of Harmful Algae, 2015 (ISBN 978-87-990827-4-2, 16 pp. (in press)).

[10] D.M. Anderson, S. McCarthy, Red tides and harmful algal blooms: Impacts on desalination operations. Middle East Desalination Research Center, Muscat, Oman. Online: www.medrc.org/download/habs_and_desaliantion_workshop_report_final.pdf2012.

[11] D.M. Anderson, A.D. Cembella, G.M. Hallegraeff, Progress in understanding harmfu algal blooms: paradigm shifts and new technologies for research, monitoring and management, Annu. Rev. Mar. Sci. 4 (2012) 143-176.

[12] S.H.S. Arruda-Fatibello, A.A. Henriques-Vieira, O. Fatibello-Filho, A rapid spectrophotometric method for the determination of transparent exopolymer particles (TEP) in freshwater, Talanta 62 (1) (2004) 81-85.

[13] K. Azetsu-Scott, U. Passow, Ascending marine particles: significance of transparent exopolymer particles (TEP) in the upper ocean, Limnol. Oceanogr. 49 (3) (2004) 741-748.

[14] J.S. Baker, L.Y. Dudley, Biofouling in membrane systems - a review, Desalination $118(1-3)(1998)$ 81-89.

[15] A. Bakun, Global climate change and intensification of coastal ocean upwelling, Science 247 (1990) 198-201.

[16] E. Bar-Zeev, N. Belkin, B. Liberman, T. Berman, I. Berman-Frank, Rapid sand filtration pretreatment for SWRO: microbial maturation dynamics and filtration efficiency of organic matter, Desalination 286 (2012) 120-130.

[17] E. Bar-Zeev, N. Belkin, B. Liberman, I. Berman-Frank, T. Berman, Bioflocculation: chemical free, pretreatment technology for the desalination industry, Water Res. 47 (9) (2013) 3093-3102.

[18] E. Bar-Zeev, I. Berman-Frank, O. Girshevitz, T. Berman, Revised paradigm of aquatic biofilm formation facilitated by microgel transparent exopolymer particles, PNAS 109 (23) (2012) 9119-9124.
[19] E. Bar-Zeev, I. Berman-Frank, B. Liberman, E. Rahav, U. Passow, T. Berman, Transparent exopolymer particles: potential agents for organic fouling and biofilm formation in desalination and water treatment plants, Desalin. Water Treat. 3 (1-3) (2009) 136-142.

[20] E. Bar-Zeev, U. Passow, S. Romero-Vargas Castrillón, M. Elimelech, Transparent exopolymer particles (TEP): from aquatic environments and engineered systems to membrane biofouling, Environ. Sci. Technol. (2015). http://dx.doi.org/10.1021/ es5041738.

[21] G. Berge, Discoloration of the sea due to Coccolithus huxleyi bloom, Sarsia 6 (1962) $27-40$.

[22] A. Berktay, Environmental approach and influence of red tide to desalination process in the middle-east region, Int. J. Chem. Environ. Eng. 2 (3) (2011) 183-188.

[23] T. Berman, Transparent exopolymer particles as critical agents in aquatic biofilm formation: implications for desalination and water treatment, Desalin. Water Treat. 51 (4-6) (2013) 1014-1020.

[24] T. Berman, M. Holenberg, Don't fall foul of biofilm through high TEP levels, Filtr. Sep. 42 (4) (2005) 30-32.

[25] T. Berman, R. Mizrahi, C.G. Dosoretz, Transparent exopolymer particles (TEP): a critical factor in aquatic biofilm initiation and fouling on filtration membranes, Desalination 276 (1-3) (2011) 184-190.

[26] P.V. Bhaskar, N.B. Bhosle, Microbial extracellular polymeric substances in marine biogeochemical processes, Curr. Sci. 88 (1) (2005) 45-53.

[27] C. Binnie, M. Kimber, G. Smethurst, Basic Water Treatment, 3rd ed. Royal Society of Chemistry, Cambridge, 2002. 59-71.

[28] S. Boerlage, N. Nada, Algal toxin removal in seawater desalination processes, Desalin. Water Treat. (2014). http://dx.doi.org/10.1080/19443994.2014.947785.

[29] S.F.E. Boerlage, M. Kennedy, Z. Tarawneh, R. De Faber, J.C. Schippers, Development of the MFI-UF in constant flux filtration, Desalination 161 (2) (2004) 103-113.

[30] S.F.E. Boerlage, M.D. Kennedy, M.P. Aniye, E.M. Abogrean, D.E.Y. El-Hodali, Z.S. Tarawneh, J.C. Schippers, Modified fouling index - ultrafiltration to compare pretreatment processes of reverse osmosis feed water, Desalination 131 (1-3) (2000) 201-214.

[31] B.C. Booth, P. Larouche, S. Bélanger, B. Klein, D. Amiel, Z. Mei, Dynamics of Chaetoceros socialis blooms in the north water, Deep-Sea Res. II 49 (22-23) (2002) 5003-5025.

[32] A. Brehant, V. Bonnelye, M. Perez, Comparison of MF/UF pretreatment with conventional filtration prior to RO membranes for surface seawater desalination, Desalination 144 (2002) 353-360.

[33] D.C. Burrell, Carbon flow in fjords, Oceanogr. Mar. Biol. Annu. Rev. 26 (1988) 143-226.

[34] M. Busch, R. Chu, S. Rosenberg, Novel trends in dual membrane systems for seawater desalination: minimum primary pretreatment and low environmental impact treatment schemes, IDA J. Desalin. Water Reuse 2 (1) (2010) 56-71.

[35] California Water Technologies, Technical bulletin on drinking water treatment with ferric chloride. Available at http://www.californiawatertechnologies.com/ pdf/PotableBulletin.pdf2004.

[36] D.A. Caron, M.E. Garneau, E. Seubert, M.D.A. Howard, L. Darjany, A. Schnetzer, I. Cetinic, G. Filteau, P. Lauri, B. Jones, S. Trussell, Harmful algae and their potential impacts on desalination operations of southern California, Water Res. 44 (2010) 385-416.

[37] J.B. Castaing, A. Masse, V. Sechet, N.E. Sabiri, M. Pontie, J. Haure, P. Jaouen, Immersed hollow fibres microfiltration (MF) for removing undesirable micro-algae and protecting semi-closed aquaculture basins, Desalination 276 (1-3) (2011) 386-396.

[38] A.D. Cembella, Chemical ecology of eukaryotic microalgae in marine ecosystems, Phycologia 42 (4) (2003) 420-447

[39] W.C. Chin, M.V. Orellana, P. Verdugo, Spontaneous assembly of marine dissolved organic matter into polymer gels, Nature 391 (1998) 568-572.

[40] R. Danovaro, S. Fonda-Umani, A. Pusceddu, Climate change and the potential spreading of marine mucilage and microbial pathogens in the Mediterranean Sea, PLoS ONE 4 (9) (2009) e7006. http://dx.doi.org/10.1371/journal.pone.0007006.

[41] A.W. Decho, Microbial exopolymer secretions in ocean environments: their role(s) in food webs and marine processes, Oceanogr. Mar. Biol. Annu. Rev. 28 (1990) 73-153.

[42] A.H.A. Dehwah, S. Al-Mashharawi, N. Kammourieb, T.M. Missimer, Impact of well intake systems on bacterial, algae and organic carbon reduction in SWRO desalination systems, SAWACO, Jeddah, Saudi Arabia, Desalin. Water Treat. (2015). http://dx.doi.org/10.1080/19443994.2014.940639 (in press).

[43] DesalData, Worldwide Desalination Inventory (MS Excel Format), 2014. (downloaded from DesalData.com (GWI/IDA) on February 2, 2014).

[44] V. Discart, M.R. Bilad, S. Van Nevel, N. Boon, J. Cromphout, I.F.J. Vankelecom, Role of transparent exopolymer particles on membrane fouling in a full-scale ultrafiltration plant: feed parameter analysis and membrane autopsy, Bioresour. Technol. 173 (2014) 67-74.

[45] M.B. Dixon, C. Falconet, L. Ho, C.W.K. Chow, B.K. O'Neill, G. Newcombe, Removal of cyanobacterial metabolites by nanofiltration from two treated waters, J. Hazard. Mater. 188 (1-3) (2011) 288-295.

[46] M.B. Dixon, C. Falconet, L. Ho, C.W.K. Chow, B.K. O'Neill, G. Newcombe, Nanofiltration for the removal of algal metabolites and the effects of fouling, Water Sci. Technol. 61 (5) (2010) 1189-1199.

[47] L. Dramas, J.P. Croué, Ceramic membrane as a pretreatment for reverse osmosis: interaction between marine organic matter and metal oxides, Desalin. Water Treat. 51 (7-9) (2013) 1781-1789.

[48] J.K. Edzwald, Dissolved air flotation and me, Water Res. 44 (2010) 2077-2106.

[49] J.K. Edzwald, J. Haarhoff, Seawater pretreatment for reverse osmosis: chemistry, contaminants, and coagulation, Water Res. 45 (2011) 5428-5440. 
[50] G. Eshel, H. Elifantz, S. Nuriel, M. Holenberg, T. Berman, Microfiber filtration of lake water: impacts on TEP removal and biofouling development, Desalin. Water Treat. 51 (4-6) (2013) 1043-1049.

[51] C.B. Field, M.J. Behrenfeld, J.T. Randerson, P. Falkowski, Primary production of the biosphere: integrating terrestrial and oceanic components, Science 281 (1998) 237-240.

[52] H.-C. Flemming, J. Wingender, Relevance of microbial extracellular polymeric substances (EPSs)-part I: structural and ecological and ecological aspects, Water Sci. Technol. 43 (6) (2001) 1-8.

[53] H.C. Flemming, Biofouling in water systems-cases, causes and countermeasures, Appl. Microbiol. Biotechnol. 59 (2002) 629-640.

[54] H.C. Flemming, G. Schaule, T. Griebe, J. Schmitt, A. Tamachkiarowa, Biofouling-the Achilles heel of membrane processes, Desalination 113 (2) (1997) 215-225.

[55] G.E. Fogg, The ecological significance of extracellular products of phytoplankton photosynthesis, Bot. Mar. 26 (1983) 3-14

[56] S. Fonda-Umani, A. Beran, S. Parlato, D. Virgilio, T. Zollet, A. De Olazabal, B. Lazzarini, M. Cabrini, Noctiluca scintillans Macartney in the Northern Adriatic Sea: long-term dynamics, relationships with temperature and eutrophication, and role in the food web, J. Plankton Res. 26 (5) (2004) 545-561.

[57] C.J. Gabelich, W.R. Chen, T.I. Yun, B.M. Coffey, I.H. Suffet, The role of dissolved aluminium in silica chemistry for membrane processes, Desalination 180 (1-3) (2005) 307-319.

[58] C.J. Gabelich, K.P. Ishida, F.W. Gerringer, R. Evangelista, M. Kalyan, I.H. Suffet, Control of residual aluminium from conventional treatment to improve reverse osmosis performance, Desalination 190 (1-3) (2006) 147-160.

[59] M. Gamal Khedr, Membrane fouling problems in reverse osmosis desalination applications, Desal. Water Reuse 10 (2000) 8-17.

[60] D. Gille, W. Czolkoss, Ultrafiltration with multi-bore membranes as seawater pretreatment, Desalination $182(1-3)$ (2005) 301-307.

[61] M. Gledhill, K.N. Buck, The organic complexation of iron in the marine environment: a review, Front. Microbiol. 3 (2012) 69.

[62] P. Glueckstern, M. Priel, M. Wilf, Field evaluation of capillary UF technology as a pretreatment for large seawater RO systems, Desalination 147 (2002) 55-62.

[63] O. Gotsis-Skretas, Mucilage appearances in Greek waters during 1982-1994, Sci. Total Environ. 165 (1995) 229-230.

[64] R. Gregory, Summary of general developments in DAF for water treatment since 1976, Proceedings Dissolved Air Flotation Conference. The Chartered Institution of Water and Environmental Management, London, 1997, pp. 1-8.

[65] A.R. Guastalli, F.X. Simon, Y. Penru, A. de Kerchove, J. Llorens, S. Baig, Comparison of DMF and UF pretreatments for particulate material and dissolved organic matter removal in SWRO desalination, Desalination 322 (2013) 144-150.

[66] C. Hallé, P.M. Huck, S. Peldszus, J. Haberkamp, M. Jekel, Assessing the performance of biological filtration as pretreatment to low pressure membranes for drinking water, Environ. Sci. Technol. 43 (10) (2009) 3878-3884.

[67] G.M. Hallegraeff, A review of harmful algal blooms and their apparent global increase, Phycologia 32 (1993) 79-99.

[68] D.F. Halpern, J. McArdle, B. Antrim, UF pretreatment for SWRO: pilot studies, Desalination 182 (2005) 323-332.

[69] W. Hamza, M.R. Enan, H. Al-Hassini, J.-B. Stuut, D. de-Beer, Dust storms over the Arabian Gulf: a possible indicator of climate changes consequences, Aquat. Ecosyst. Health Manag. 14 (3) (2011) 260-268.

[70] S.G.J. Heijman, M.D. Kennedy, G.J. van Hek, Heterogeneous fouling in dead-end ultrafiltration, Desalination 178 (1-3) (2005) 295-301.

[71] S.G.J. Heijman, M. Vantieghem, S. Raktoe, J.Q.J.C. Verberk, J.C. van Dijk, Blocking of capillaries as fouling mechanism for dead-end ultrafiltration, J. Membr. Sci. 287 (1) (2007) 119-125.

[72] R. Henderson, S.A. Parsons, B. Jefferson, The impact of algal properties and preoxidation on solid-liquid separation of algae, Water Res. 42 (8-9) (2008) 1827-1845.

[73] R.K. Henderson, A. Baker, S.A. Parsons, B. Jefferson, Characterisation of algogenic organic matter extracted from cyanobacteria, green algae and diatoms, Water Res. 42 (2008) 3435-3445.

[74] R.K. Henderson, S.A. Parsons, B. Jefferson, The potential for using bubble modification chemicals in dissolved air flotation for algae removal, Sep. Sci. Technol. 44 (9) (2009) 1923-1940.

[75] G. Huang, F. Meng, X. Zheng, Y. Wang, Z. Wang, H. Liu, M. Jekel, Biodegradation behavior of natural organic matter (NOM) in a biological aerated filter (BAF) as a pretreatment for ultrafiltration (UF) of river water, Appl. Microbiol. Biotechnol. 90 (5) (2011) 1795-1803.

[76] S.A. Huber, A. Balz, M. Abert, W. Pronk, Characterisation of aquatic humic and nonhumic matter with size-exclusion chromatography-organic carbon detection-organic nitrogen detection (LC-OCD-OND), Water Res. 45 (2011) 879-885.

[77] M. Innamorati, Hyperproduction of mucilages by micro and macro algae in the Tyrrhenian sea, Sci. Total Environ. 165 (1995) 65-81.

[78] J.F. Jacobs, M.N. Hasan, K.H. Paik, W.R. Hagen, M.C.M. van Loosdrecht, Development of a bionanotechnological phosphate removal system with thermostable ferritin, Biotechnol. Bioeng. 105 (2010) 918-923.

[79] J.D. Jacobson, M.D. Kennedy, G. Amy, J.C. Schippers, Phosphate limitation in reverse osmosis: an option to control biofouling? Desalin. Water Treat. 5 (1-3) (2009) 198-206.

[80] S. Jamaly, N.N. Darwish, I. Ahmed, S.W. Hasan, A short review on reverse osmosis pretreatment technologies, Desalination 354 (2014) 30-38.

[81] I. Janse, M. Van Rijssel, J.C. Gottschal, C. Lancelot, W.W.C. Gieskes, Carbohydrates in the North Sea during spring blooms of Phaeocystis: a specific fingerprint, Aquat. Microb. Ecol. 10 (1996) 97-103.

[82] M.D. Kennedy, F.P. Muñoz Tobar, G. Amy, J.C. Schippers, Transparent exopolymer particle (TEP) fouling of ultrafiltration membrane systems, Desalin. Water Treat. 6 (1-3) (2009) 169-176.
[83] H.-G. Kim, An overview on the occurrences of harmful algal blooms (HABs) and mitigation strategies in Korean coastal waters, in: A. Ishimatsu, H.-J. Lie (Eds.), Coastal Environmental and Ecosystem Issues of the East China Sea, 2010, pp. 121-131.

[84] S.H. Kim, J.S. Yoon, Optimization of microfiltration for seawater suffering from redtide contamination, Desalination 182 (1-3) (2005) 315-321.

[85] R. Komlenic, T. Berman, J.A. Brant, B. Dorr, I. El-Azizi, H. Mowers, Removal of polysaccharide foulants from reverse osmosis feed water using electroadsorptive cartridge filters, Desalin. Water Treat. 51 (4-6) (2013) 1050-1056.

[86] M. Kurihara, M. Hanakawa, Mega-ton water system: Japanese national research and development project on seawater desalination and wastewater reclamation, Desalination 308 (2013) 131-137.

[87] D.A. Ladner, D.R. Vardon, M.M. Clark, Effects of shear on microfiltration and ultrafiltration fouling by marine bloom-forming algae, J. Membr. Sci. 356 (2010) 33-43.

[88] C. Lancelot, The mucilage phenomenon in the continental coastal waters of the north sea, Sci. Total Environ. 165 (1995) 83-102.

[89] M.V. Laycock, D.M. Anderson, J. Naar, A. Goodman, D.J. Easy, M.A. Donovan, A. Li, M.A. Quilliam, E. Al Jamali, R. Alshihi, R. Alshihi, Laboratory desalination experiments with some algal toxins, Desalination 293 (2012) 1-6.

[90] S. Le Gallou, S. Bertrand, K.H. Madan, Full coagulation and dissolved air flotation: a SWRO key pretreatment step for heavy fouling seawater, Proceedings of International Desalination Association World Congress, Perth, Australia, 2011.

[91] J.A. Leenheer, J.P. Croué, Characterizing aquatic dissolved organic matter: understanding the unknown structures is key to better treatment of drinking water, Environ. Sci. Technol. 37 (1) (2003) 18A-26A.

[92] C. Legrand, K. Rengefors, G.O. Fistarol, E. Granéli, Allelopathy in phytoplankton biochemical, ecological and evolutionary aspects, Phycologia 42 (4) (2003) 406-419.

[93] G.G. Leppard, The characterization of algal and microbial mucilages and their aggregates in aquatic ecosystems, Sci. Total Environ. 165 (1995) 103-131.

[94] G.G. Leppard, A. Massalski, D.R.S. Lean, Electron-opaque microscopic fibrils in lakes: their demonstration, their biological derivation, and their potential significance in the redistribution of cations, Protoplasma 92 (1977) 289-309.

[95] G.G. Leppard, Organic flocs in surface waters: their native state and aggregation behavior in relation to contaminant dispersion, in: S.S. Lewis (Ed.), Rao, Particulate Matter and Aquatic Contaminants, Boca Raton, FL, 1993, pp. 169-195.

[96] A. Lerch, W. Uhl, R. Gimbel, CFD modelling of floc transport and coating layer buildup in single UF/MF membrane capillaries driven in inside-out mode, Water Sci. Technol. Water Supply 7 (4) (2007) 37-47.

[97] L. Li, N. Gao, Y. Deng, J. Yao, K. Zhang, Characterization of intracellular \& extracellular algae organic matters (AOM) of Microcystis aeruginosa and formation of AOMassociated disinfection byproducts and odor \& taste compounds, Water Res. 46 (4) (2012) 1233-1240.

[98] B. Liberman, T. Berman, Analysis and monitoring: MSC - a biologically oriented approach, Filtr. Sep. 43 (4) (2006) 39-40.

[99] S.J. Longhurst, N.J.D. Graham, Dissolved air flotation for potable water treatment: a survey of operational units in Great Britain, Public Health Eng. 14 (6) (1987) 71-76.

[100] L. MacKenzie, I. Sims, V. Beuzenberg, P. Gillespie, Mass accumulation of mucilage caused by dinoflagellate polysaccharide exudates in Tasman Bay, New Zealand Harmful Algae 1 (2002) (2002) 69-83.

[101] G. Maier, G.A. Glegg, A.D. Tappin, P.J. Worsfold, A high resolution temporal study of phytoplankton bloom dynamics in the eutrophic Taw Estuary (SW England), Sci. Total Environ. 434 (2012) 228-239.

[102] G.B. McGregor, I. Stewart, B.C. Sendall, R. Sadler, K. Reardon, S. Carter, D. Wruck, W Wickramasinghe, First report of a toxic Nodularia spumigena (Nostocales/ Cyanobacteria) bloom in sub-tropical Australia. I. Phycological and Public Health Investigations, Int. J. Environ. Res Public Health 9 (2012) 2396-2411.

[103] M. Mingazzini, B. Thake, Summary and conclusions of the workshop on marine mucilages in the Adriatic sea and elsewhere, Sci. Total Environ. 165 (1995) 9-14.

[104] T.M. Missimer, Water Supply Development, Aquifer Storage, and Concentrate Disposal for Membrane Water Treatment Facilities, 2nd edition Schlumberger Limited, Sugar Land, Texas, 2009.

[105] T.M. Missimer, N. Ghaffour, H.A. Dehwah, R. Rachman, R.G. Maliva, G. Amy, Subsurface intakes for seawater reverse osmosis facilities: capacity limitation, water quality improvement, and economics, Desalination 322 (2013) 37-51.

[106] K. Mopper, J. Zhou, K. Sri Ramana, U. Passow, H.G. Dam, D.T. Drapeau, The role of surface-active carbohydrates in the flocculation of a diatom bloom in a mesocosm, Deep-Sea Res. II 42 (1) (1995) 47-73.

[107] P.W. Mote, N.J. Mantua, Coastal upwelling in a warmer future, Geophys. Res. Lett. 29 (23) (2002) 2138.

[108] S.M. Myklestad, Phytoplankton extracellular production and leakage with considerations on the polysaccharide accumulation, Ann. Ist. Super. Sanita 35 (3) (1999) 401-404.

[109] S.M. Myklestad, Release of extracellular products by phytoplankton with special emphasis on polysaccharides, Sci. Total Environ. 165 (1995) 155-164.

[110] G. Naidu, S. Jeong, S. Vigneswaran, S.A. Rice, Microbial activity in biofilter used as a pretreatment for seawater desalination, Desalination 309 (2013) 254-260.

[111] N. Nazzal, Red tide' shuts desalination plant. Gulf News, Dubai, UAE. Available from http://gulfnews.com/news/gulf/uae/environment/red-tide-shuts-desalinationplant-1.590952009.

[112] N.P. Nezlin, I.G. Polikarpov, F.Y. Al-Yamani, D.V. Subba Rao, A.M. Ignatov, Satellite monitoring of climatic factors regulating phytoplankton variability in the Arabian (Persian) gulf, J. Mar. Syst. 82 (1-2) (2010) 47-60.

[113] T. Nguyen, F.A. Roddick, L. Fan, Biofouling of water treatment membranes: a review of the underlying causes, monitoring techniques and control measures, Membranes 2 (4) (2012) 804-840. 
[114] T. Okaichi, Red tide problems in the Seto Inland Sea, Japan, in: T. Okaichi, D.M. Anderson, T. Nemoto (Eds.), Red Tides. Biology, Environmental Science and Toxicology, Elsevier, New York, 1989, pp. 137-144.

[115] I. Olenina, S. Hajdu, L. Edler, A. Andersson, N. Wasmund, S. Busch, J. Göbel, S Gromisz, S. Huseby, M. Huttunen, A. Jaanus, P. Kokkonen, I. Ledaine, E. Niemkiewicz, Biovolumes and size-classes of phytoplankton in the Baltic Sea, HELCOM Balt, Sea Environ. Proc. 106 (2006) (ISSN 0357-2994).

[116] T.Y Orlova, G.V. Konovalova, IV. Stonik, M.S. Selina, T.V. Morozova, O.G. Shevchenko, Harmful algal blooms on the eastern coast of Russia, in: F.J.R. Taylor, V.L. Trainer (Eds.),Harmful Algal Blooms in the PICES Region of the North Pacific, PICES Sci. Rep. No. 23, 2002 (152 pp.).

[117] S. Panglisch, Formation and prevention of hardly removable particle layers in inside-out capillary membranes operating in dead-end mode, Water Sci. Technol. Water Supply 3 (5-6) (2003) 117-124

[118] T. Pankratz, Red tides close desal plants, Water Desalin. Rep. 44 (44) (2008)

[119] T. Pankratz, Surf or turf? Water Desalin. Rep. 49 (25) (2013)

[120] K.S. Park, S.S. Mitra, W.K. Yim, S.W. Lim, Algal bloom - critical to designing SWRO pretreatment and pretreatment as built in Shuwaikh, Kuwait SWRO by Doosan, Desalin. Water Treat. 51 (31-33) (2013) 1-12.

[121] U. Passow, Formation of transparent exopolymer particles (TEP) from dissolved precursor material, Mar. Ecol. Prog. Ser. 192 (2000) 1-11.

[122] U. Passow, Transparent exopolymer particles (TEP) in aquatic environments, Prog. Oceanogr. 55 (3) (2002) 287-333.

[123] U. Passow, A.L. Alldredge, Distribution, size, and bacterial colonization of transparen exopolymer particles (TEP) in the ocean, Mar. Ecol. Prog. Ser. 113 (1994) 185-198.

[124] U. Passow, A.L. Alldredge, A dye-binding assay for the spectrophotometric measurement of transparent exopolymer particles (TEP), Limnol. Oceanogr. 40 (7) (1995) 1326-1335.

[125] U. Passow, R.F. Shipe, A. Murray, D.K. Pak, M.A. Brzezinski, A.L. Alldredge, Origin of transparent exopolymer particles (TEP) and their role in the sedimentation of particulate matter, Cont. Shelf Res. 21 (2001) 327-346.

126] G. Pearce, S. Talo, K. Chida, A. Basha, A. Gulamhusein, Pretreatment options for large scale SWRO plants: case studies of UF trials at Kindasa, Saudi Arabia, and conventional pretreatment in Spain, Desalination 167 (1-3) (2004) 175-189.

[127] G.K. Pearce, The case for UF/MF pretreatment to RO in seawater applications, Desalination 203 (1-3) (2007) 286-295

[128] M. Petry, M.A. Sanz, C. Langlais, V. Bonnelye, J.-P. Durand, D. Guevara, W.M. Nardes, C.H. Saemi, The el coloso (chile) reverse osmosis plant, Desalination 203 (1-3) (2007) 141-152.

[129] S. Plantier, J.B. Castaing, N.E. Sabiri, A. Massé, P. Jaouen, M. Pontié, Performance of a sand filter in removal of algal bloom for SWRO pretreatment, Desalin. Water Treat. 51 (7-9) (2012) 1838-1846.

[130] F. Qu, H. Liang, J. He, J. Ma, Z. Wang, H. Yu, G. Li, Characterization of dissolved extracellular organic matter (dEOM) and bound extracellular organic matter (bEOM) of Microcystis aeruginosa and their impacts on UF membrane fouling Water Res. 46 (9) (2012) 2881-2890.

[131] F. Qu, H. Liang, J. Tian, H. Yu, Z. Chen, G. Li, Ultrafiltration (UF) membrane fouling caused by cyanobacteria, fouling effects of cells and extracellular organics matter (EOM), Desalination 293 (2012) 30-37.

132] R.M. Rachman, S. Li, T.M. Missimer, SWRO feed water quality improvement using subsurface intakes in Oman, Spain, Turks and Caicos Islands, and Saudi Arabia, Desalination 351 (2014) 88-100.

133] F. Ricci, N. Penna, S. Capellacci, A. Penna, Potential environmental factors influencing mucilage formation in the northern Adriatic sea, Chem. Ecol. 30 (4) (2014) 364-375.

[134] M.L. Richlen, S.L. Morton, E.A. Jamali, A. Rajan, D.M. Anderson, The catastrophic 2008-2009 red tide in the Arabian Gulf region, with observations on the identification and phylogeny of the fish-killing dinoflagellate Cochlodinium polykrikoides, Harmful Algae 9 (2) (2010) 163-172.

[135] A. Rinaldi, R.A. Vollenweider, G. Montanari, C.R. Ferrari, A. Ghetti, Mucilages in Italian seas: The Adriatic and Tyrrhenian seas, 1988-1991, Sci. Total Environ. 165 (1995) 165-183.

[136] R. Rosberg, Ultrafiltration (new technology), a viable cost-saving pretreatment for reverse osmosis and nanofiltration - a new approach to reduce costs, Desalination 110 (1-2) (1997) 10-113.

[137] J.M. Rovel, Why a SWRO in Taweelah - pilot plant results demonstrating feasibility and performance of SWRO on Gulf water? Proceedings of International Desalination Association World Congress, Nassau, Bahamas, 2003.

[138] S.G. Salinas-Rodríguez, M.D. Kennedy, J.C. Schippers, G.L. Amy, Organic foulants in estuarine and bay sources for seawater reverse osmosis -comparing pretreatment processes with respect to foulant reduction, Desalin. Water Treat. 9 (1-3) (2009) $155-164$

[139] S.G. Salinas-Rodriguez, Particulate and Organic Matter Fouling of SWRO Systems: Characterization, Modelling and Applications(Doctoral dissertation) UNESCOIHE/TUDelft, Delft, 2011.

[140] M.A. Sanz, D. Guevara, F. Beltrán, E. Trauman, 4 stages pretreatment reverse osmosis for South-Pacific seawater: El Coloso plant (Chile), Proceedings of International Desalination Association World Congress, Singapore, 2005.

[141] Schippers (2012). Personal communications.

[142] J.C. Schippers, J. Verdouw, The modified fouling index, a method of determining the fouling characteristics of water, Desalination 32 (1980) 137-148.

[143] R. Schurer, A. Janssen, L. Villacorte, M.D. Kennedy, Performance of ultrafiltration and coagulation in an UF-RO seawater desalination demonstration plant, Desalin. Water Treat. 42 (1-3) (2012) 57-64.

[144] R. Schurer, A. Tabatabai, L. Villacorte, J.C. Schippers, M.D. Kennedy, Three years operational experience with ultrafiltration as SWRO pretreatment during alga bloom, Desalin. Water Treat. 51 (4-6) (2013) 1034-1042.
[145] M.S. Selina, G.V. Konovalova, T.V. Morozova, T.Y. Orlova, Genus Alexandrium Halim, 1960 (dinophyta) from the pacific coast of Russia: species composition, distribution, and dynamics, Russ. J. Mar. Biol. 32 (6) (2006) 321-332.

[146] K.G. Sellner, G.J. Doucette, G.J. Kirkpatrick, Harmful algal blooms: causes, impacts and detection, J. Ind. Microbiol. Biotechnol. 30 (2003) 383-406.

[147] C. Sheppard, M. Al-Husiani, F. Al-Jamali, F. Al-Yamani, R. Baldwin, J. Bishop, F. Benzoni, E. Dutrieux, N.K. Dulvy, S.R.V. Durvasula, D.A. Jones, R. Loughland, D. Medio, M. Nithyanandan, G.M. Pilling, I. Polikarpov, A.R.G. Price, S. Purkis, B. Riegl, M. Saburova, K.S. Namin, O. Taylor, S. Wilson, K. Zainal, The gulf: a young sea in decline, Mar. Pollut. Bull. 60 (1) (2010) 13-38.

[148] J.-H. Shi, H.-W. Gao, J. Zhang, S.-C. Tan, J.-L. Ren, C.-G. Liu, Y. Liu, X. Yao, Examination of causative link between a spring bloom and dry/wet deposition of Asian dust in the Yellow Sea, China, J. Geophys. Res. 117 (2012) D17304.

[149] T. Shikata, S. Nagasoe, T. Matsubara, S. Yoshikawa, Y. Yamasaki, Y. Shimasaki, Y. Oshima, I.R. Jenkinson, T. Honjo, Factors influencing the initiation of blooms of the Raphidophyte Heterosigma akashiwo and the diatom Skeletonema costatum in a port in Japan, Limnol. Oceanogr. 53 (2008) 2503-2518.

[150] T.J. Smayda, Harmful algal blooms: their ecophysiology and general relevance to phytoplankton blooms in the sea, Limnol. Oceanogr. 42 (1997) 1137-1153.

[151] V. Smetacek, A. Zingone, Green and golden seaweed tides on the rise, Nature 504 (7478) (2013) 84-88

[152] J.C. Smith, R. Cormier, J. Worms, C.J. Bird, M.A. Quilliam, R. Pocklington, R. Angus, L Hanic, Toxic blooms of the domoic acid containing diatom Nitzschia pungens in the Cardigan River, Prince Edward Island, in: E. Graneli, B. Sundström, L. Edler, D.M. Anderson (Eds.), Toxic Marine Phytoplankton, Elsevier, New York, 1990, pp. 227-232.

[153] R.P. Stumpf, M.C. Tomlinson, J.A. Calkins, B. Kirkpatrick, K. Fisher, K. Nierenberg, R Currier, T.T. Wynne, Skill assessment for an operational algal bloom forecast system, J. Mar. Syst. 76 (1-2) (2009) 151-161.

[154] S.A.A. Tabatabai, S.I. Gaulinger, M.D. Kennedy, G.L. Amy, J.C. Schippers, Optimization of inline coagulation in integrated membrane systems: a study of $\mathrm{FeCl}_{3}$, Desalin. Water Treat. 10 (1-3) (2009) 121-127.

[155] S.A.A. Tabatabai, M.D. Kennedy, G.L. Amy, J.C. Schippers, Optimizing inline coagulation to reduce chemical consumption in MF/UF systems, Desalin. Water Treat. 6 (1-3) (2009) 94-101

[156] S.A.A. Tabatabai, Coagulation and Ultrafiltration in Seawater Reverse Osmosis Pretreatment(Doctoral dissertation) UNESCO-IHE/TU Delft, Delft, 2014

[157] S.A.A. Tabatabai, J.C. Schippers, M.D. Kennedy, Effect of coagulation on fouling potential and removal of algal organic matter in ultrafiltration pretreatment to seawater reverse osmosis, Water Res. 59 (2014) 283-294.

[158] S. Taș, E. Okus, A review on the bloom dynamics of a harmful dinoflagellate Prorocentrum minimum in the golden horn estuary, Turk. J. Fish. Aquat. Sci. 11 (4) (2011) 523-531.

[159] M.R. Teixeira, M.J. Rosa, Comparing dissolved air flotation and conventional sedimentation to remove cyanobacterial cells of Microcystis aeruginosa. Part II. The effect of water background organics, Sep. Purif. Technol. 53 (1) (2007) 126-134.

[160] M.R. Teixeira, V. Sousa, M.J. Rosa, Investigating dissolved air flotation performance with cyanobacterial cells and filaments, Water Res. 44 (11) (2010) 3337-3344.

[161] B. Tenzer, A. Adin, M. Priel, Seawater filtration for fouling prevention under stormy conditions, Desalination 125 (1-3) (1999) 77-88.

[162] P.A. Tester, K. Wiles, S.M. Varnam, G. Velez Ortega, A.M. Dubois, V. Arenas Fuentes, Harmful algal blooms in the western gulf of Mexico: Karenia brevis is messin' with Texas and Mexico! in: K.A. Steidinger, J.H. Landsberg, C.R. Tomas, G.A. Vargo (Eds.), Harmful Algae 2002, Florida Fish and Wildlife Conservation Commission, Florida Institute of Oceanography, and Intergovernmental Oceanographic Commission of UNESCO, 2004, pp. 41-43

[163] A. Teuler, K. Glucina, J.M. Laine, Assessment of UF pretreatment prior to RO membranes for seawater desalination, Desalination 125 (1999) 89-96.

[164] D.C.O. Thornton, E.M. Fejes, S.F. DiMarco, K.M. Clancy, Measurement of acid polysaccharides (APS) in marine and freshwater samples using Alcian blue, Limnol. Oceanogr. 5 (2007) 73-87.

[165] V.L. Trainer, N.G. Adams, B.D. Bill, B.F. Anulacion, J.C. Wekell, Concentration and dispersal of a Pseudo-nitzschia bloom in Penn Cove, Washington, USA, Nat. Toxins 6 (1998) 113-125.

[166] F.M. Van Dolah, Marine algal toxins: origins, health effects, and their increased occurrence, Environ. Health Perspect. 108 (Suppl. 1) (2000) 133

[167] S.C.J.M. van Hoof, A. Hashim, A.J. Kordes, The effect of ultrafiltration as pretreatment to reverse osmosis in wastewater reuse and seawater desalination applications, Desalination 124 (1999) 231-242.

[168] S. van Nevel, T. Hennebel, K. De Beuf, G. Du Laing, W. Verstraete, N. Boon, Transparent exopolymer particle removal in different drinking water production centers, Water Res. 46 (11) (2012) 3603-3611.

[169] J. van Puffelen, P.J. Buijs, P.N.A.M. Nuhn, W.A.M. Hijen, Dissolved air flotation in potable water treatment: the Dutch experience, Water Sci. Technol. 31 (3-4) (1995) 149-157.

[170] P. Verdugo, A.L. Alldredge, F. Azam, D.L. Kirchman, U. Passow, P.H. Santschi, The oceanic gel phase: a bridge in the DOM-POM continuum, Mar. Chem. 92 (2004) 67-85.

[171] L.O. Villacorte, S.A.A. Tabatabai, N. Dhakal, G. Amy, J.C. Schippers, M.D. Kennedy, Algal blooms: an emerging threat to seawater reverse osmosis desalination, Desalin. Water Treat. (2015). http://dx.doi.org/10.1080/19443994.2014.940649 (in press).

[172] LO. Villacorte, Algal Blooms and Membrane Based Desalination Technology(Doctoral dissertation) UNESCO-IHE/TUDelft, Delft, 2014

[173] L.O. Villacorte, Y. Ekowati, H.N. Calix-Ponce, G.L. Amy, J.C. Schippers, M.D. Kennedy, Improved method for measuring transparent exopolymer particles (TEP) and their precursors in fresh and saline water, Water Res. 70 (1) (2015) 300-312. 
[174] L.O. Villacorte, Y. Ekowati, H. Winters, G.L. Amy, J.C. Schippers, M.D. Kennedy, Characterisation of transparent exopolymer particles (TEP) produced during algal bloom: a membrane treatment perspective, Desalin. Water Treat. 51 (4-6) (2013) 1021-1033.

[175] L.O. Villacorte, M.D. Kennedy, G.L. Amy, J.C. Schippers, The fate of transparent exopolymer particles (TEP) in integrated membrane systems: removal through pretreatment processes and deposition on reverse osmosis membranes, Water Res. 43 (20) (2009) 5039-5052.

[176] L.O. Villacorte, M.D. Kennedy, G.L. Amy, J.C. Schippers, Measuring transparent exopolymer particles (TEP) as indicator of the (bio)fouling potential of RO feed water, Desalin. Water Treat. 5 (2009) 207-212.

[177] L.O. Villacorte, R. Schurer, M. Kennedy, G. Amy, J.C. Schippers, The fate of transparent exopolymer particles in integrated membrane systems: a pilot plant study in Zeeland, The Netherlands, Desalin. Water Treat. 13 (2010) 109-119.

[178] L.O. Villacorte, R. Schurer, M. Kennedy, G. Amy, J.C. Schippers, Removal and deposition of transparent exopolymer particles (TEP) in seawater UF-RO system, IDA J. 2 (1) (2010) 45-55.

[179] A. Vlaski, Microcystis aeruginosa Removal by Dissolved Air Flotation (DAF): Options for Enhanced Process Operation and Kinetic Modelling(Doctoral dissertation) IHE/ TUD, Delft, 1997.

[180] N. Voutchkov, Considerations for selection of seawater filtration pretreatment system, Desalination 261 (3) (2010) 354-364.

[181] J.S. Vrouwenvelder, F. Beyer, K. Dahmani, N. Hasan, G. Galjaard, J.C. Kruithof, M.C.M. Van Loosdrecht, Phosphate limitation to control biofouling, Water Res. 44 (11) (2010) 3454-3466.

[182] J.S. Vrouwenvelder, D. van der Kooij, Diagnosis, prediction and prevention of biofouling of NF and RO membranes, Desalination 139 (1-3) (2001) 65-71.

[183] J.S. Vrouwenvelder, J.A.M. van Paassen, L.P. Wessels, A.F. van Dam, S.M. Bakker, The membrane fouling simulator: a practical tool for fouling prediction and control, J. Membr. Sci. 281 (1-2) (2006) 316-324.
[184] J.J. Walsh, K.A. Steidinger, Saharan dust and Florida red tides: the cyanophyte connection, J. Geophys. Res. 106 (C6) (2001) 11597-11612.

[185] WaterWorld, Fujairah hybrid desalination plant to expand with dissolved air flotation system. Available at: http://www.waterworld.com/articles/2013/01/fujairah-hybriddesalination-plant-to-expand-with-dissolved-air-floatation-system.html2013.

[186] WHO, Desalination for Safe Water Supply, Guidance for the Health and Environmental Aspects Applicable to Desalination, World Health Organization (WHO), Geneva, 2007.

[187] M. Wilf, M.K. Schierach, Improved performance and cost reduction of RO seawater systems using UF pretreatment, Desalination 135 (2001) 61-68.

[188] H. Winters, I.R. Isquith, In-plant microfouling in desalination, Desalination 30 (1) (1979) 387-399.

[189] P.H. Wolf, S. Siverns, S. Monti, UF membranes for RO desalination pretreatment, Desalination 182 (2005) 293-300.

[190] T. Wynne, R.P. Stumpf, M.C. Tomlinson, J. Dyble, Characterizing a cyanobacterial bloom in western Lake Erie using satellite imagery and meteorological data, Limnol. Oceanogr. 55 (2010) 2025-2036.

[191] Y. Zhang, J. Tian, J. Nan, S. Gao, H. Liang, M. Wang, G. Li, Effect of PAC addition on immersed ultrafiltration for the treatment of algal-rich water, J. Hazard. Mater. $186(2-3)$ (2011) 1415-1424.

[192] I.X. Zhu, B.J. Bates, D.M. Anderson, Removal of Prorocentrum minimum from seawater using dissolved air flotation, J. Appl. Water Eng. Res. (2014). http://dx.doi.org/ $10.1080 / 23249676.2014 .924440$.

[193] S.G. Salinas Rodriguez, M.D. Kennedy, G.L. Amy, J.C. Schippers, Flux dependency of particulate/colloidal fouling in seawater reverse osmosis systems, Desalination and Water Treatment 42 (2012) 155-162. 